\title{
39. THE SOURCE AREA FOR LOWER CRETACEOUS CLASTIC SEDIMENTS OF THE GALICIA MARGIN: GEOLOGY AND TECTONIC AND EROSIONAL HISTORY ${ }^{1}$
}

\author{
Edward L. Winterer, Jeffrey S. Gee, and Robert J. Van Waasbergen, \\ Scripps Institution of Oceanography, La Jolla, California
}

\begin{abstract}
Structural relations shown on seismic-reflection profiles of the Galicia margin indicate that during the Early Cretaceous rifting of the margin, Galicia Bank and its southern extension (Galicia Ridge) were separated from the mainland of Iberia by a fault-controlled trough, and that the rift-stage sandy turbidite sediments in the fault troughs west of Galicia Bank were derived from the erosion of a narrow row of rugged hills that occupied the present area of Galicia Bank and Ridge. The volume and age span of rift-stage clastic sediments, estimated from drill and seismic data, imply rapid erosion of about $1 \mathrm{~km}$ of bedrock in the source area, suggesting that the source area was uplifted tectonically during the early stage of rifting. The composition of the sandstone indicates a source area dominated by granitic and schistose rocks, consistent with data from dredge hauls. The abundant fragmental plant debris in the sandstone indicates heavily wooded land, and regional sedimentological and paleobotanical data suggest warm rainy climatic conditions. A combination of erosional lowering (largely compensated by isostatic rebound) and tectonic subsidence reduced most of the source area to sea level by the Aptian, and carbonate banks then flourished over the site of the former landmass.
\end{abstract}

\section{INTRODUCTION}

Drilling on the Galicia margin (Fig. 1) during Ocean Drilling Program (ODP) Leg 103 demonstrated that much of the thickness of Lower Cretaceous rift-stage sediments consists of quartzofeldspathic sandstone deposited by turbidity currents (site chapters of the Initial Reports; Boillot, Winterer, et al., 1987). The preliminary shipboard data on composition and texture of the sandstone suggested that the sand is first-cycle material, eroded from nearby wooded lands that exposed crystalline rocks. The considerable thickness of these sandy sediments seen on seismic sections across the Galicia margin poses several related questions:

1. Where exactly was the source area(s)?

2. What were its areal dimensions and height?

3. What were the roles of tectonism and isostasy in creating and maintaining its relief?

4. What was the geology of the source area?

5. What was its climate?

To explore these questions, we studied the mineralogy of a suite of sandstone samples to learn something of the geology and climate of the source area and then used available seismicreflection data to identify, on structural and stratigraphic grounds, the source areas. We also use the seismic profiles to estimate the volume of rift-stage sandy sediments derived from the source area, and, finally, we estimate the height of the source area and speculate on the tectonic significance of our findings.

\section{Regional Relations}

Lower Cretaceous rocks, both from the continents around the North Atlantic and from the adjacent submerged continental margins and deep seas, are commonly very sandy. On the conti-

\footnotetext{
${ }^{1}$ Boillot, G., Winterer, E. L., et al., 1988. Proc. ODP, Sci. Results, 103: College Station, TX (Ocean Drilling Program).
}

nents, they comprise mainly sandy and muddy fluviatile, swamp and deltaic sediments commonly referred to as the Wealden. These strata generally form a distinctive clastic wedge between underlying carbonate platform and evaporitic beds below, and more open-water marine sediments above. Their regional distribution is shown on paleogeographic maps by Ziegler (1982) and von Rad and Sarti (1985). Their stratigraphy and sedimentology have been documented by Allen $(1969,1972,1981)$ and by Sladen and Batten (1984) for the areas around the English Channel; by Amiot et al. (1982) and Pujalte (1982) for northern Spain; by Wilson (1975), Wilson and Exton (1979), and Montenat et al. (this volume) for the Lusitanian Basin of Portugal; by Wiedmann et al. (1982) for northwest Africa; by McWhae (1982) for the Scotian Shelf and Grand Banks; and by Mattick et al. (1982) and Poag (1982) for the northern part of the United States shelf.

Lower Cretaceous clastic rocks of deep-water, turbidite facies, similar to those recovered in cores at the Leg 103 sites, are also known from cores from the continental rise of northwest Africa (Lancelot and Winterer, 1980; Winterer and Hinz, 1984), from uplifted rocks of the rise exposed in the Canary Islands (Robertson and Bernoulli, 1982), from the Biscay margin of France (Montadert et al., 1979), and from the deep western North Atlantic (Sarti and von Rad, 1987).

The significance of this great volume of clastic sediments is yet only poorly understood. Climate changes, from arid to humid, probably played a role. In some places there is a shift from carbonates and evaporites in the Upper Jurassic to fluviatile and coaly and swampy facies in the Lower Cretaceous. There was also tectonism, expressed by regional uplift and faulting in northwest Europe (Allen, 1981), Iberia, northwest Africa, the Grand Banks and Scotia margins, and the northern part of the United States Atlantic margin (reviewed in Wilson, 1975; von Rad and Sarti, 1986). In some places, for example in the Lusitanian Basin, the faulting was most intense in the Late Jurassic, but over much of the region the most active faulting was during the Early Cretaceous in the $20 \mathrm{~m}$.y. or so that preceded the beginning of seafloor spreading in the segment of the Atlantic north of the Azores Fracture Zone. 


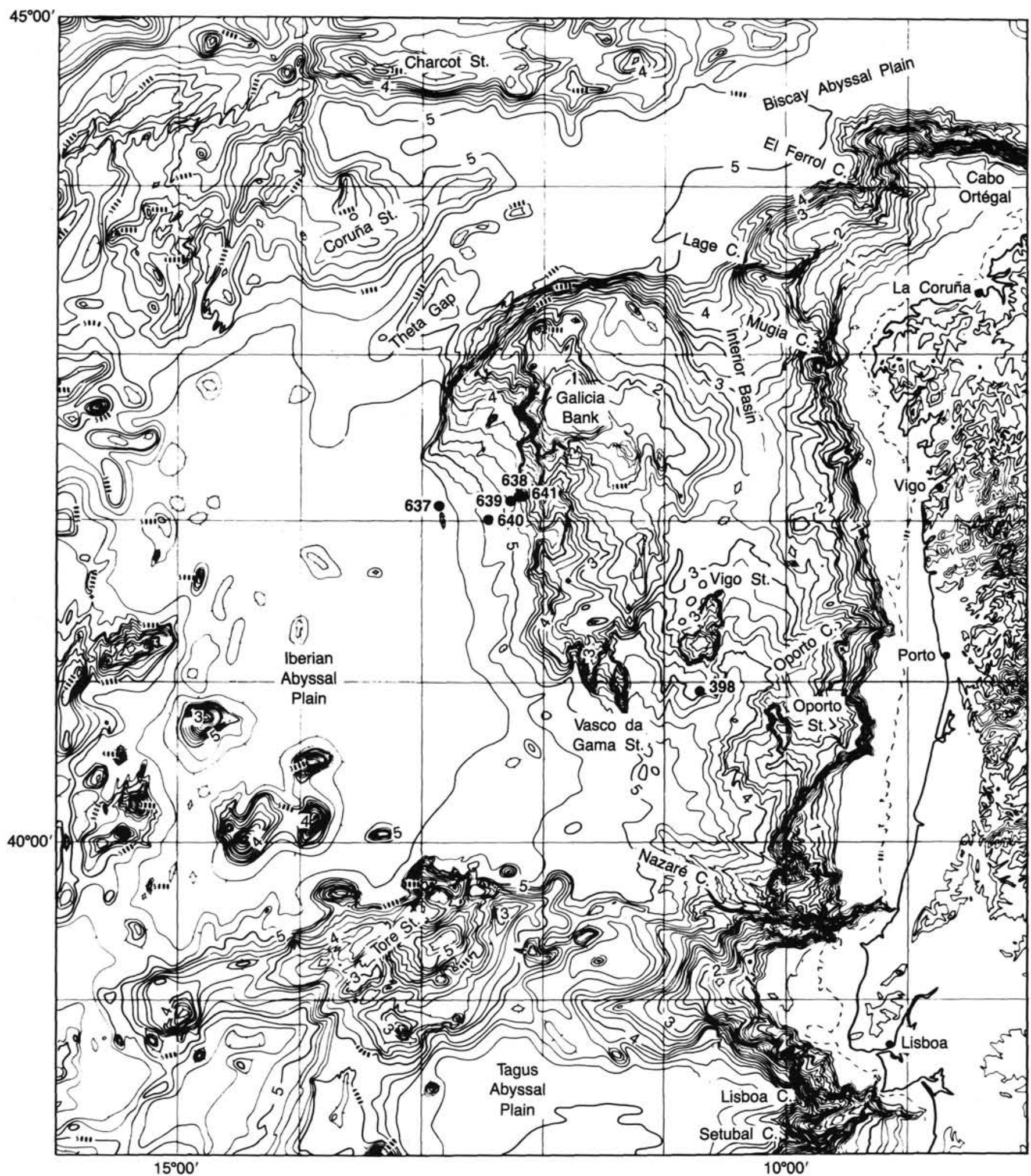

Figure 1. The continental margin and adjacent deep seafloor west of the Iberian Peninsula, showing Galicia bank and the sites drilled during ODP Leg 103 (637-641) and DSDP Leg 47, Part 2 (398) (from Thommeret et al., this volume). 


\section{Lower Cretaceous Stratigraphy of Galicia Margin}

Multichannel seismic-reflection profiles across the outer, western part of the Galicia margin (Pls. 1 and 2 and Figs. 2 and 3) show thick wedges of rift-stage sediments with complex internal stratigraphy partly filling half-grabens bounded by seaward-dipping normal faults. Two seismic units within the rift sequence can be recognized over most of the area (Mauffret and Montadert, this volume): an upper unit that is fairly well layered (seismic Unit 4), and a lower, more complexly layered unit (seismic Unit 5). In many places Unit 4 is separated from Unit 5 by a surface of slight angular discordance, and local angular unconformities are common within Unit 5. Drilling during Leg 103 (Boillot, Winterer, et al., 1987) showed that Unit 5 (upper Valanginian and lower Hauterivian) is composed of turbidite sandstone and mudstone, and Unit 4 (Hauterivian to Aptian) of marlstone, claystone, pelagic limestone, and turbidites and debris-flow deposits, which were partly derived from coeval shallow-water carbonate-platform debris.

The tilted-wedge geometry of the rift-stage sequences and the numerous internal unconformities (onlap, toplap, and downlap) seen on the seismic profiles indicate that the faulting that created the half-grabens preceded the start of sand accumulation in Valanginian time and continued episodically until near the end of the Aptian. The faults do not displace post-Aptian (post-rift) sediments.

The coring at Leg 103 sites revealed two discrete intervals of rift-stage coarse clastics: a lower interval (upper Valanginian and lower Hauterivian) dominated by quartzo-feldspathic turbidite sandstone, and an upper interval (upper Barremian and Aptian) that includes turbidite and debris-flow units composed primarily of shallow-water carbonate-platform sediments. The abundance of these two types is plotted on Figure 4, using the raw thickness data as measured in the cores, and on Figure 5, where the data are normalized for core recovery. Sediments between the two intervals of coarse clastics are mainly nannofossil marlstone, limestone, and claystone.

\section{DESCRIPTIVE PETROLOGY}

\section{Mineralogy}

To characterize the petrology of the sandstone beds, we examined a suite of 11 thin sections cut from samples from Site 638,2 sections from Site 640, and 1 from Hole 639A. Most of the samples are from medium- to coarse-grained sandstone, which we selected in the belief that rock fragments, twinned feldspars, and other valuable clues to source-area petrology are more likely found in coarser than in finer grain sizes. We recognize that fine grains from the source area escape our attention, and if there is a significant volume of such grains (e.g., from fine-grained sedimentary or metamorphic rocks in the source area) we will not detect this.

For each section, at least $\mathbf{3 0 0}$ grains were point counted. The results are displayed (Fig. 6) as bar graphs. The bar lengths are weighted to exaggerate small percentages. The percentages for detrital framework grains (including grains replaced by calcite) have been normalized to $100 \%$, and the measured percentage of calcite cement that originally filled pores is shown in a separate column. For some slides, the mineralogy of grains partly replaced by calcite is tabulated; for other slides, these grains are totaled together. Ferroan calcite was identified with potassium ferricyanide stain.

The point counts show a striking consistency of mineral composition. Taking into account the calcite replacements and not counting void-filling cement, the average composition of the detrital fraction in samples from Site 638 and Hole 639A, of late Valanginian and early Hauterivian age, is about:

$\begin{array}{lc}\text { Quartz } & 52 \% \\ \text { Feldspar } & 28 \\ \text { Biotite } & 5 \\ \text { Muscovite } & \text { trace } \\ \text { Rock fragments } & 11 \\ \text { Detrital carbonate } & 2 \\ \text { Opaque minerals } & 2\end{array}$

Samples from Site 640, of Barremian and Aptian age, contain $15 \%-40 \%$ detrital shallow-water carbonate grains, with the other minerals in about the same relative proportions as in the older sandstone beds.

The quartz is mainly monocrystalline, with moderately undulose extinction. About a third of the grains are polycrystalline, mostly with only a few subgrains separated by fairly straight boundaries, and differing by only a few degrees in extinction positions. The coarser-grained samples have the largest proportions of polycrystalline grains. Most quartz grains contain curving lines of tiny vacuoles (Fig. 7). The feldspars include orthoclase (19\%), microcline (1\%) (Fig. 8 ), and plagioclase $(8 \%)$. The feldspar most susceptible to replacement by calcite is plagioclase (Figs. 9A and 9B), followed by orthoclase and microcline. Many feldspar grains are dotted with sericite, commonly aligned along cleavage directions (Fig. 7). Micas are more abundant in fine-grained than in coarse-grained samples. Biotite commonly shows oxidation weathering effects (Fig. 9A). The rock fragments are mainly quartz-mica schist, along with rare fragments of pyritic shale. Resedimented carbonate grains, such as peloids (Fig. 10), ooids, and micritized fragments of pelecypods and benthic foraminifers (Fig. 8), are minor constituents in most slides. The opaque minerals are mainly tiny diagenetic pyrite crystals, aggregated into small clumps and most commonly associated with biotite, micritic carbonate grains, and especially with nearly opaque woody plant material, which we include in the opaque category in the point counts. Visual study of the cores aboard the drilling vessel (Boillot, Winterer, et al., 1987) showed the presence of abundant $(3 \%-5 \%)$ terrestrial plant debris in some sandstone layers (Fig. 15). Accessory minerals are rare, and include sphene, zircon, garnet, tourmaline, spinel, and phosphorite grains. In a few slides we noted rare grains of glauconite.

\section{Texture}

Although the original shapes of detrital grains are obscured in places by the irregularities along the replacement front between grains and diagenetic cement, the photomicrographs (Figs. 7-11) show that the grains were angular to subangular when deposited. No well-rounded grains or worn authigenic overgrowths, indicative of multicycling of sediments, were seen.

The grain sizes shown on Figure 6 are averages of the measured cross-sectional diameters of the point-counted grains. The photomicrographs show a very large range of cross-sectional grain diameters in the thin sections, which suggests somewhat poor size sorting. On the other hand, there was about $20 \%$ $25 \%$ porosity in the rocks at the time of cementation.

\section{Cementation and Diagenesis}

Ferroan calcite typically constitutes $35 \%-40 \%$ of the volume of the sandstone samples and occupies two sites: (1) cement that fills original pore spaces, averaging about $23 \%$ of the volume of the rocks and (2) replacements of parts of detrital grains, averaging about $15 \%$ of the rock volume. The estimate of the amount of replacement is minimal because of the difficulty in counting the innumerable veinlets and tiny blebs of calcite that riddle unstable framework grains (Figs. 9-11); some plagioclase grains may in fact have been entirely replaced, leaving only a faint dusty ghost in the calcite. The grain size of the cementing and 

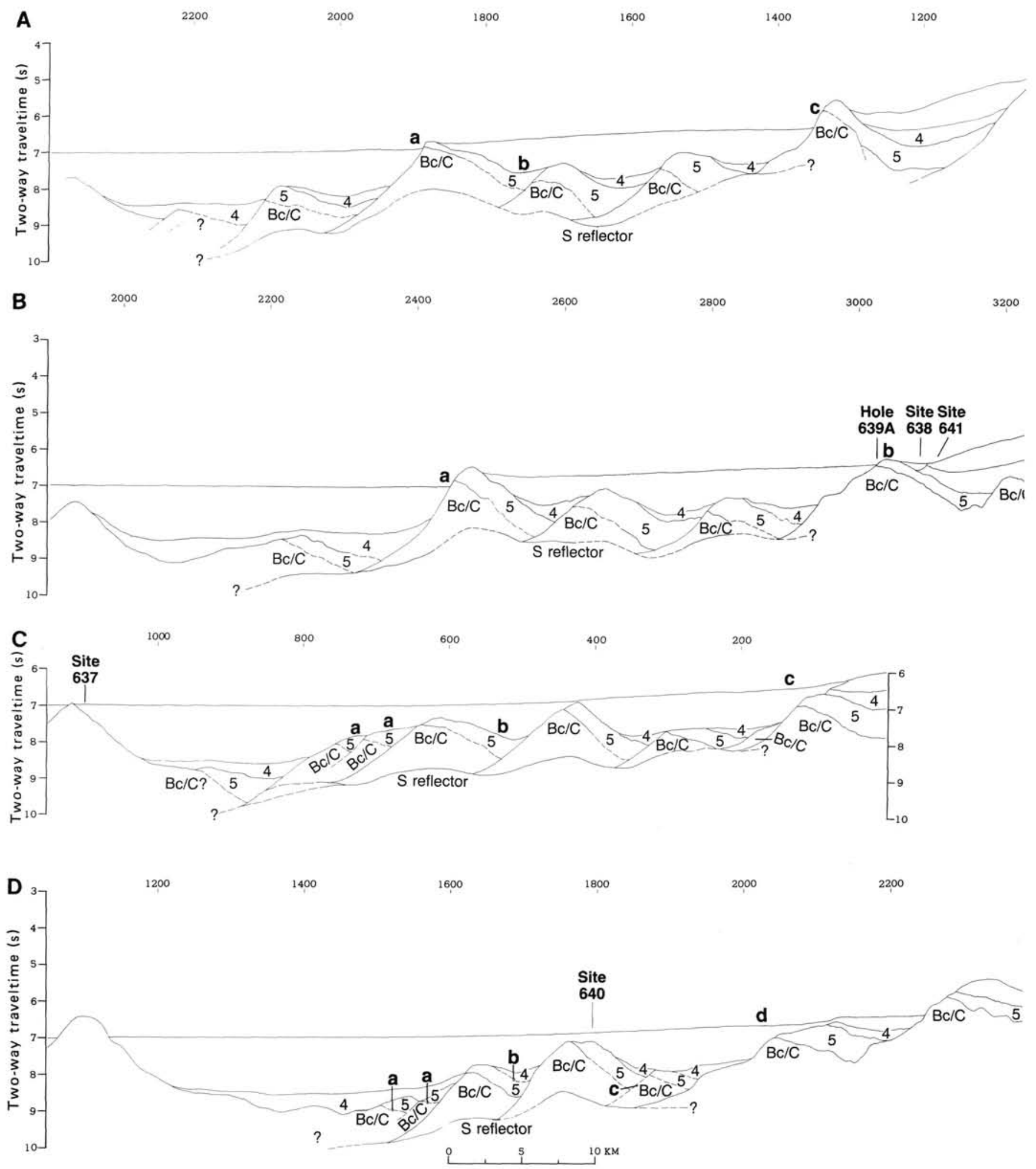

Figure 2. Interpretive line drawings of seismic-reflection profiles of the Galicia margin in the vicinity of the Leg 103 drill sites. Horizontal scale, 100 shotpoints $=5 \mathrm{~km}$; scale bar on Figure 2D (profile GP-102B1). Vertical scale is two-way traveltime in seconds. Seismic Units 4 and 5 and basement and carbonate-platform rocks are labeled. Units 1-3 (post-rift, Albian-Recent) are not labeled. ODP drill sites are projected onto profiles. Letters on profiles are keyed to comments for parts A-D. A. Profile GP-11. a. Crystalline basement outcrops have been confirmed on the correlative ridge on B (profile GP-101) (Boillot et al., 1986). b. Some Unit 4 may be present. c. Drilling at Site 639, on the corresponding ridge on GP-101, revealed subcrops of Jurassic carbonates and crystalline basement. B. Profile GP-101. a. Submersible dives recovered granodiorite providing control for the presence and thickness of Unit 5 (Boillot et al., 1986). Along the north and south extensions of this ridge, and on ridges immediately to the east and west, the base of Unit 5 has been chosen on a reflector compatible with the relations at $\mathrm{a}$. b. The diffraction pattern of the northerly continuation of the hill 
1000 800

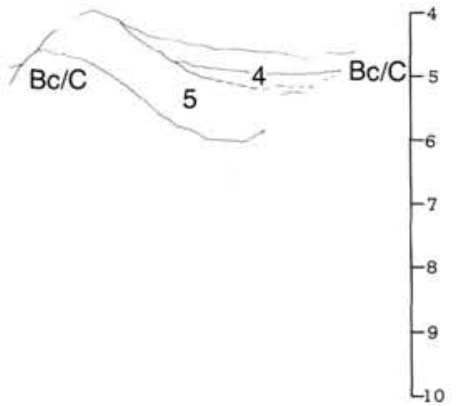

3400

3800

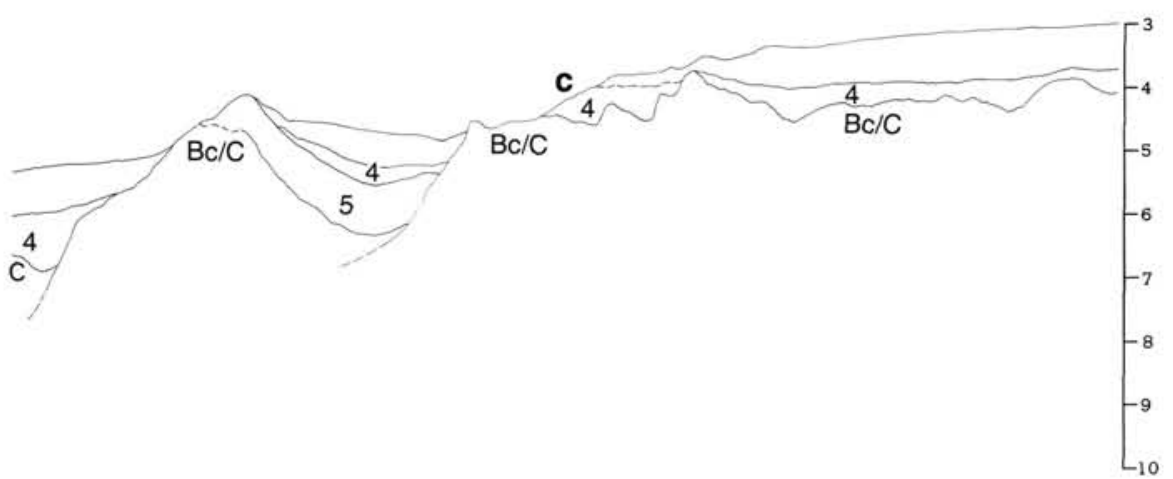

2400

$2600 \quad 2800$

3000

3200

3400

3600 $\mathrm{Bc} / \mathrm{C}$ $\mathrm{Bc} / \mathrm{C} \sim 4$
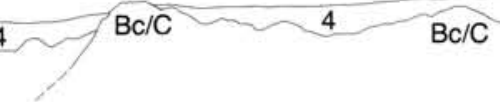
$\mathrm{Bc} / \mathrm{C}$

$\mathrm{Bc} / \mathrm{C}$
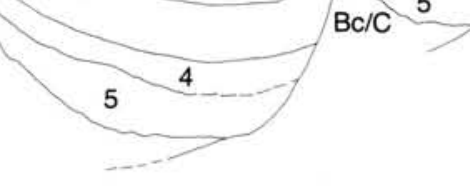

has been removed. The seismic stratigraphy is well known in the vicinity of Sites 638,639 , and 641 . c. This interval has been interpreted as Unit 4 because (1) a strong reflector, identified as the break-up unconformity at the base of the Aptian/Albian black shale (seismic Unit 3), is visible in many places, and (2) Unit 5 is not known to occur on the Galicia Ridge (Shipboard Scientific Party, 1979). C. Profile GP-12. a. This area is particularly disturbed, but Unit 4 does not appear to be present. b. Some Unit 4 may be present. c. Note overall similarity of structure to that of Figure 2B (profile GP-10) at shotpoints 2900-3000. D. Profile GP-102B1. a. Identification of Bc/C and Unit 5 uncertain. b. The character of reflectors suggests that Unit 4 is present, but the boundary between Units 4 and 5 is somewhat arbitrary. c. Although the interpretation of the reflectors in this area is unclear, the presence of a corresponding structure on Figure 2A-2C (profiles GP-11, GP-101, and GP-12) suggests that there is a small fault block here. The fault forming the western boundary of the block is suggested by termination of the lower reflectors of Unit 4 , but other contacts are speculative. d. Note overall structural similarity with Figures 2B and 2C (profiles GP-101 and GP-12). 


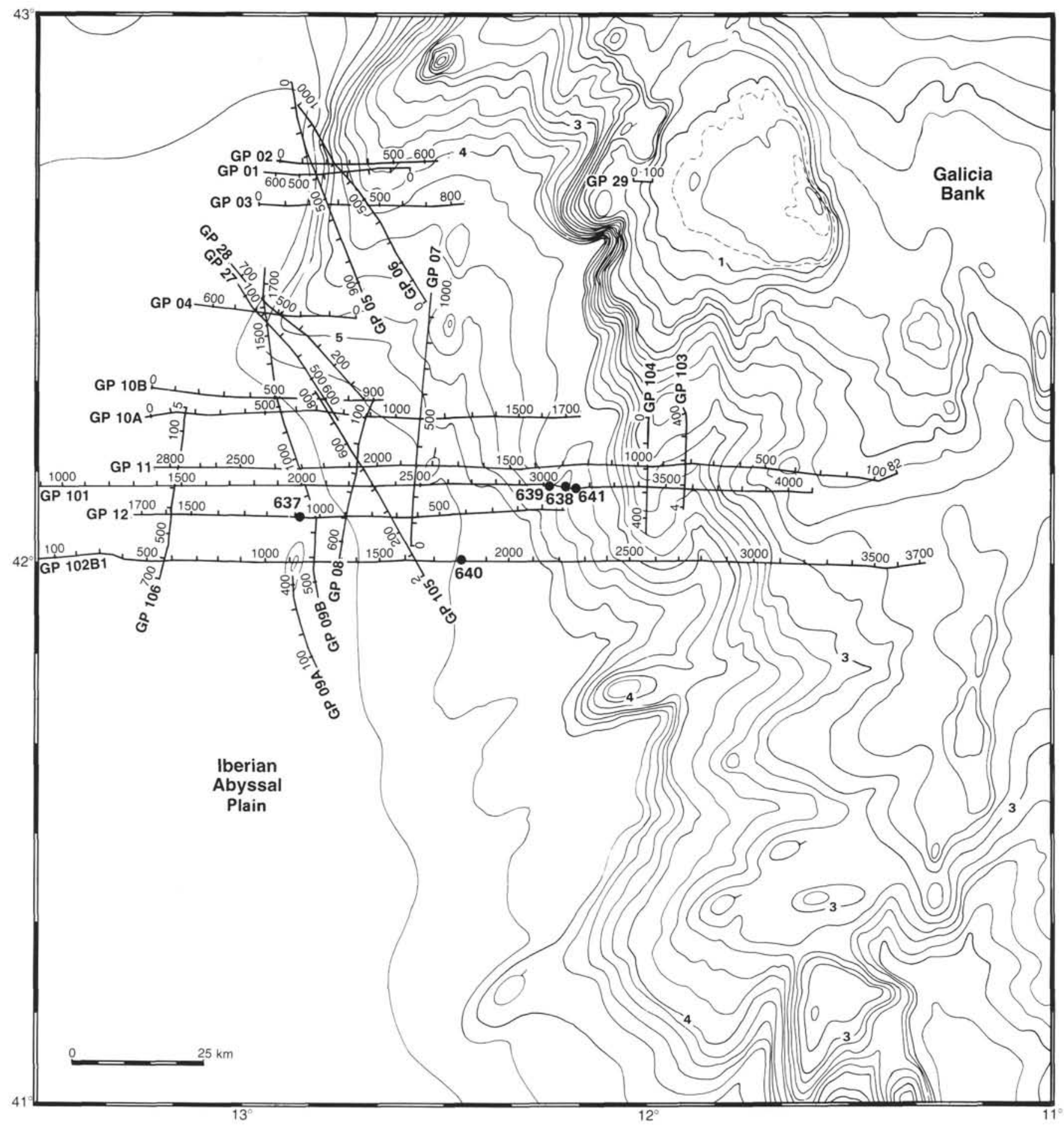

Figure 3. Location of seismic profiles shown in Plates 1 and 2 and in Figures 2 and 14. The numbers along the track lines are shotpoints and correspond to numbers along the top of the profiles.

replacing calcite is generally large, with single crystals commonly filling not only an entire pore space but also extending in optical continuity as replacing calcite within adjacent detrital grains. In some places the calcite crystals are even larger and poikilitically enclose several detrital grains (Fig. 9B). There is no trace of any earlier generation of cement.

\section{Jurassic Sandstone from Hole 639D}

Sandstone interbedded in Upper Jurassic (Tithonian) shallow-water limestone in Hole 639D (Boillot, Winterer, et al.,
1987 ) is mineralogically only slightly different from the turbidite sandstone from Site 638. Our point counts of just two thin sections from coarse-grained samples of this Jurassic sandstone (Fig. 6) show:
Quartz

Feldspar

Rock fragments

Opaque minerals
$65 \%$

30

3

2 


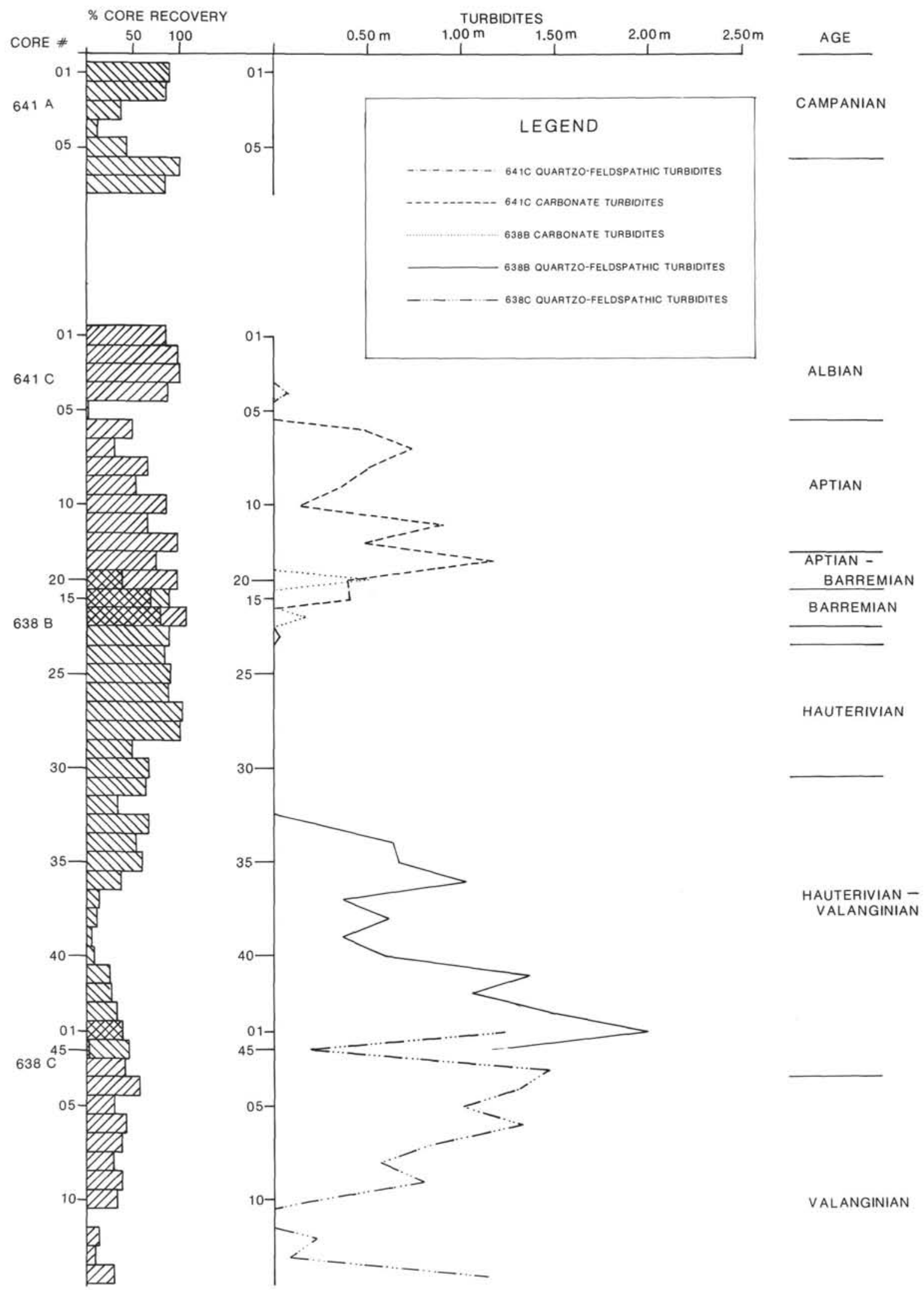

Figure 4. Cumulative thickness of turbidite layers in each core from the Lower Cretaceous of Sites 638 and 641 , not normalized for core recovery. 
E. L. WINTERER, J. S. GEE, R. F. VAN WAASBERGEN

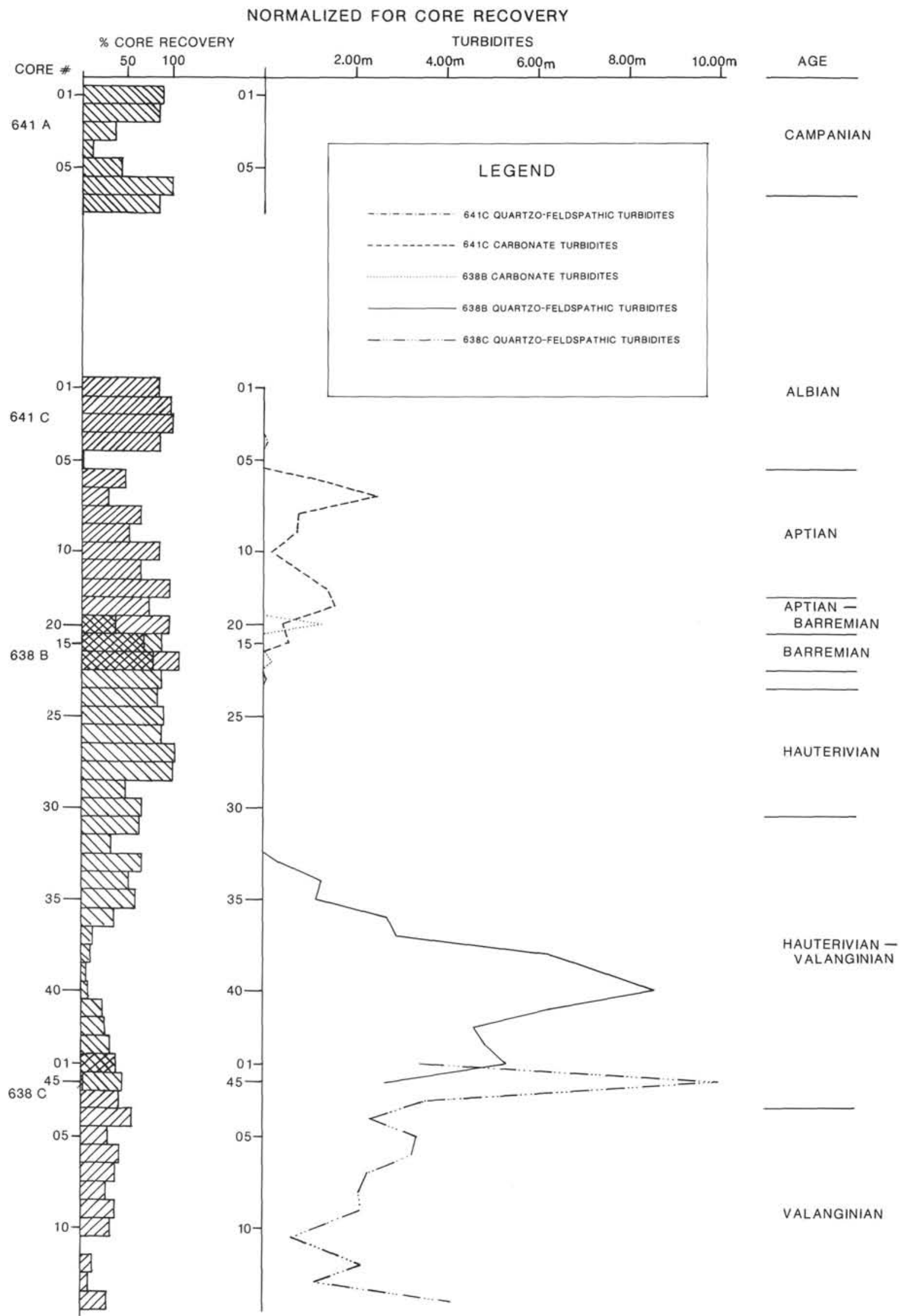

Figure 5. Cumulative thickness of turbidite layers in each core from the Lower Cretaceous of Sites 638 and 641 , normalized for full core recovery. 

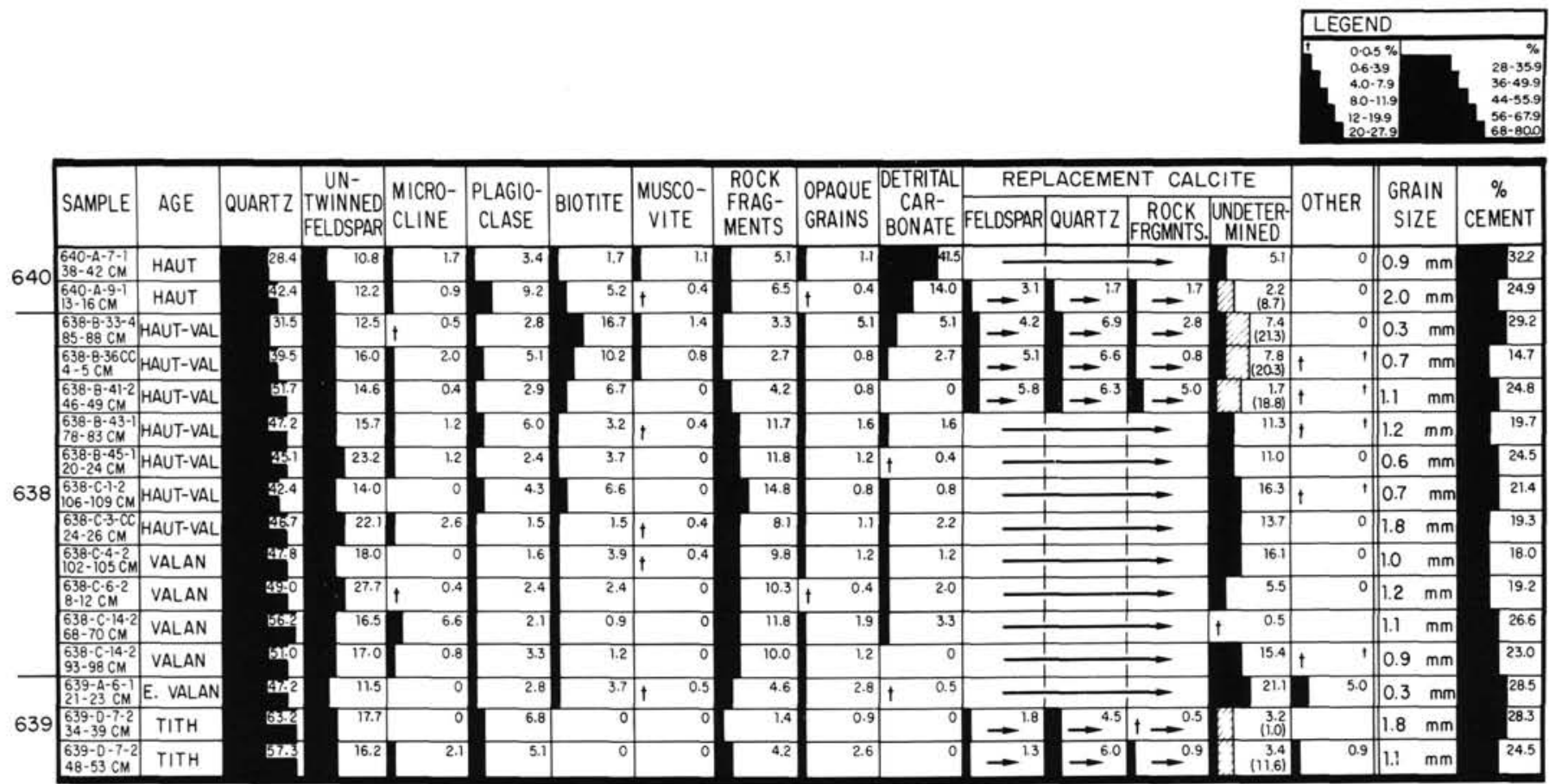

Moroccan Margin

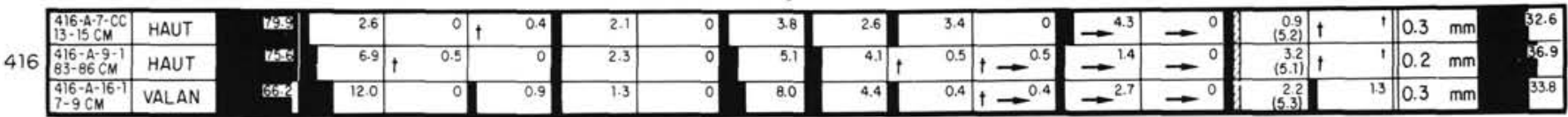

Western North Atlantic and Vigo Seamount

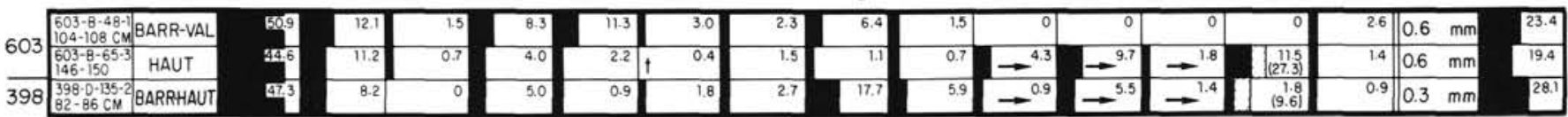

Figure 6. Mineral percentages in thin sections of Lower Cretaceous and Upper Jurassic sandstone, Galicia margin. Data from point counts of about 300 grains in each slide. The percentages of detrital grains are treated as totaling $100 \%$, and the percentage of calcite cement is shown separately.

No mica is present, possibly because of the coarse grain size. We do not regard the slight differences in composition between the samples of Jurassic and Cretaceous sandstone as having any significance, given the small number of samples and the possible effects of grain size on composition. The grains are angular, and the mineralogy indicates first-cycle material.

\section{SOURCE AREA}

\section{Inferences from Petrology}

For both the Lower Cretaceous and Upper Jurassic sandstone, the high feldspar content and the angularity of the sand grains are indicative of a first-cycle sediment, derived directly from moderately fresh crystalline rocks. The sandstone mineralogy suggests plutonic igneous and possibly metamorphic rocks of acid to intermediate composition and schistose metasedimentary rocks. The relatively high proportion of quartz is most likely due to removal of feldspar during weathering in a humid climate. Basu (1976) reports that quartz percentages in Holocene coarse-grained sands are roughly doubled over their percentages in their Appalachian granitic source rocks in the humid climate of the Appalachians.

A source area with geologic conditions like almost any part of the Spanish Meseta could fulfill the petrologic requirements for the sandstone of seismic Unit 5, because the bulk bedrock compositional differences among the various tectonic zones that make up the Meseta are not great. A study of published geologic maps of the entire Iberian Meseta (Sabas, 1966; Julivert et al., 1977) shows the following areal distribution of major rock types (measurements by planimeter):

$\begin{array}{crc}\text { Paleozoic acid plutons } & 55,616 \mathrm{~km}^{2} & 27.7 \% \\ \text { basic plutons } & 2,043 & 1.0 \\ \text { sedimentary rocks } & 100,364 & 50.0 \\ \text { metamorphic rocks } & 23,641 & 11.8 \\ \text { Precambrian, undifferentiated } & 19,069 & 9.5\end{array}$

Studies of crystalline rock samples dredged from the west Iberian margin, including the area on and west of Galicia Bank by Capdevila and Mougenot (this volume), suggest that the bedrock of the Galicia Bank region consists mainly of calc-alkaline granite, granodiorite and quartz diorite, and peraluminous granite intrusive into deformed mudstone, sandstone, and some calcareous sediments, metamorphosed in greenschist and amphibolite facies. According to Capdevila and Mougenot, the rocks most resemble those in the Ossa-Morena tectonic zone of the Iberian mainland, a zone that trends northwest across the southwest part of the Meseta and swings north to underlie the Lusitanian Basin and possibly the Galicia Bank region.

For the upper, resedimented carbonates of Unit 4, a local carbonate bank or reef is required as a source. Some of the 


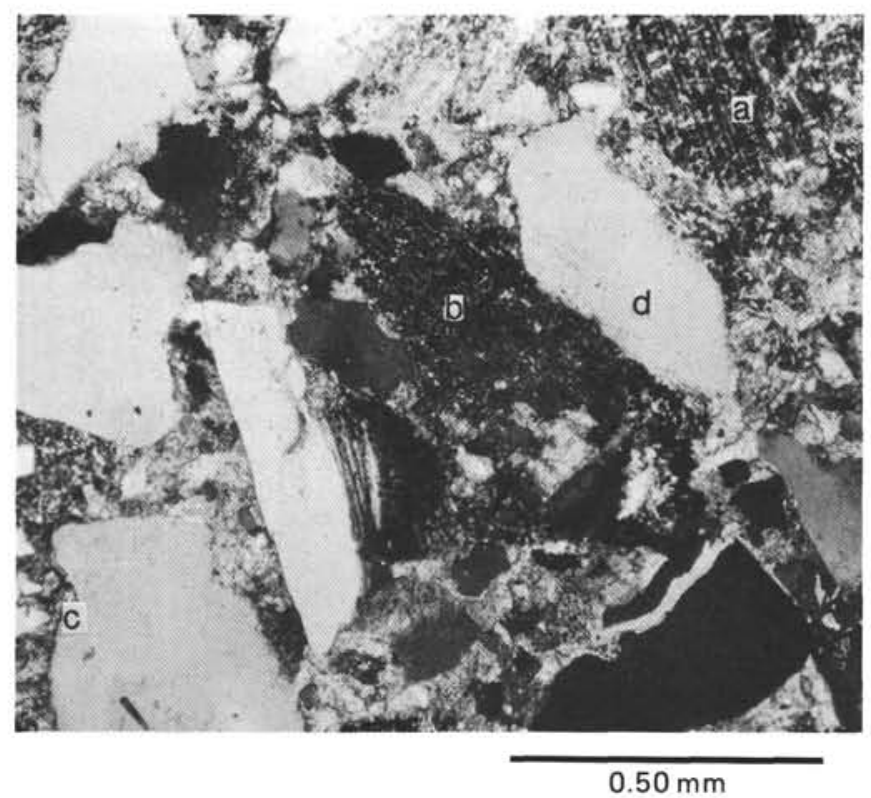

Figure 7. Photomicrograph of sandstone consisting of angular quartz, twinned (a) and untwinned feldspars, and a metamorphic rock fragment (b). Quartz grains are embayed and fretted by replacing calcite (c) and marked by curved trails of vacuoles (d). Sample 103-638B-45R-1, 20-24 $\mathrm{cm}$.

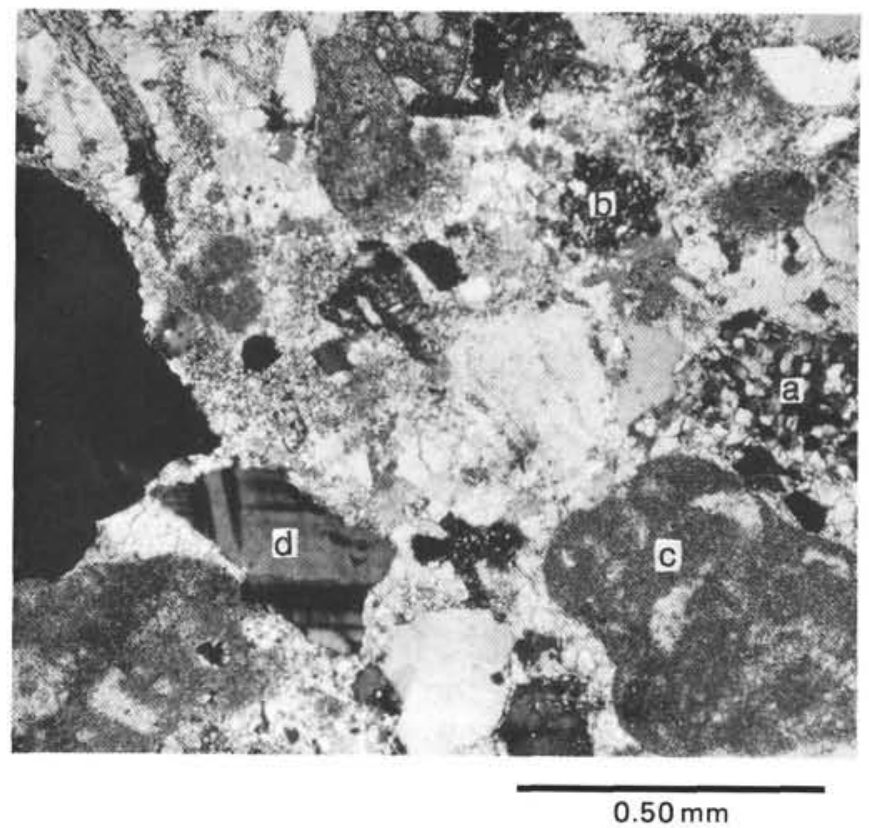

Figure 8. Photomicrograph of sandstone with quartz, feldspar (d), metasedimentary rock fragments $(a, b)$, and abundant grains of detrital carbonate (c, micritized benthic foraminifer). Sample 103-640A-7R-1, $38-42 \mathrm{~cm}$.

limestone clasts are many centimeters in diameter, and none shows any sign of wear or rounding.

\section{Location}

Multichannel seismic-reflection profiles from the vicinity of the Leg 103 drill sites, made available by L. Montadert (Pls. 1 and 2 and Figs. 2 and 3), clearly show that the sandy sediments of Valanginian and early Hauterivian age (seismic Unit 5) are thickest in the half-grabens toward the eastern end of the profiles. This thickening indicates that the source area for the sediments was on the Iberian rather than the Newfoundland side of the regional rift system.

A regional bathymetric map (Fig. 1) shows that the western part of the Galicia margin is some $200 \mathrm{~km}$ distant from the Iberian coast and is separated from the mainland by a long submarine ridge that continues north to join Galicia Bank. Between the ridge and the mainland is the Interior Basin, a wide trough that can be traced continuously from the Bay of Biscay to Vigo Seamount and beyond. Seismic profiles (Groupe Galice, 1979) (Fig. 12) show that the trough is a composite graben consisting of north-trending normal faults that define a broad sag subdivided into narrower horsts and grabens. In some places there is one central deep graben (profile OC-105), but in others there is more than one graben (profile OC-104). The profiles also show that the smaller graben(s) in the trough contain a very thick fill of both rift and post-rift sediments. These data suggest that the trough had its origins during Early Cretaceous rifting or perhaps an even earlier episode of rifting (Réhault and Mauffret, 1979), and that it probably acted as a trap for Cretaceous clastic sediments brought westward by streams flowing off the Iberian mainland to the coast.

The position of the basins in the Interior Basin, between the crystalline massif of the Iberian Meseta to the east and an offshore basement high to the west, is analogous to the position of the basins on- and offshore Portugal. The fault-controlled Lusitanian Basin lies adjacent to the Meseta on the Portuguese mainland, and is paralleled offshore by a series of horsts and sediment-filled grabens. These basins had their inception in Late Triassic/Early Jurassic rifting, and were rejuvenated by faulting in Late Jurassic and again in Early Cretaceous time (Wilson and Exton, 1979; Montenat et al., this volume). The presence of diapiric structures in the Interior Trough (Réhault and Mauffret, 1979) suggests that it may also have had its origins in Late Triassic/Jurassic rifting and have a history analogous to that of the Lusitanian Basin. We lack both deep-penetration multichannel seismic data and drill holes to test this hypothesis adequately, but we accept the schematic connections shown in Figure 13 (from Montenat et al., this volume) as a plausible arrangement.

If, as here suggested, the Iberian mainland was an unlikely source area for the Early Cretaceous rift-stage sediments of the western Galicia margin, could the source area rather have been Galicia Bank and its southern ridge extension? Several lines of evidence point strongly in favor of this hypothesis. Dredging and coring show that beneath the Cenozoic cover of pelagic sediments, Galicia Bank itself is capped by Upper Cretaceous carbonate-platform strata (Groupe Galice, 1979), and drilling at Site 641 suggests that carbonate reefs flourished on the perimeter of the bank during late Barremian and Aptian times as well (Boillot, Winterer, et al., 1987). Although seismic profil records do not reveal the character of rocks underlying the the platform sediments on Galicia Bank, the dredges recovered crystalline basement rocks from the bank edges at shallow depths, and there is little vertical space into which any pre-Barremian deep-water sediments could be fitted. We interpret these data as suggesting that Galicia Bank has a long history as a high-standing block. One supporting piece of evidence for an early presence of high ground in the region is the already described sandstone interbedded in the shallow-water limestone of Tithonian age in Hole 639D.

Galicia Bank continues both northwest, as a ridge visible in the bathymetry (Fig. 1), and southward, as a ridge of pre-rift rocks, directly overlain by post-rift sediments, running from Galicia Bank for about $130 \mathrm{~km}$, almost to Vasco da Gama and Vigo seamounts. The ridge may continue southward to connect with the Berlengas horst, offshore from the Lusitanian Basin of 


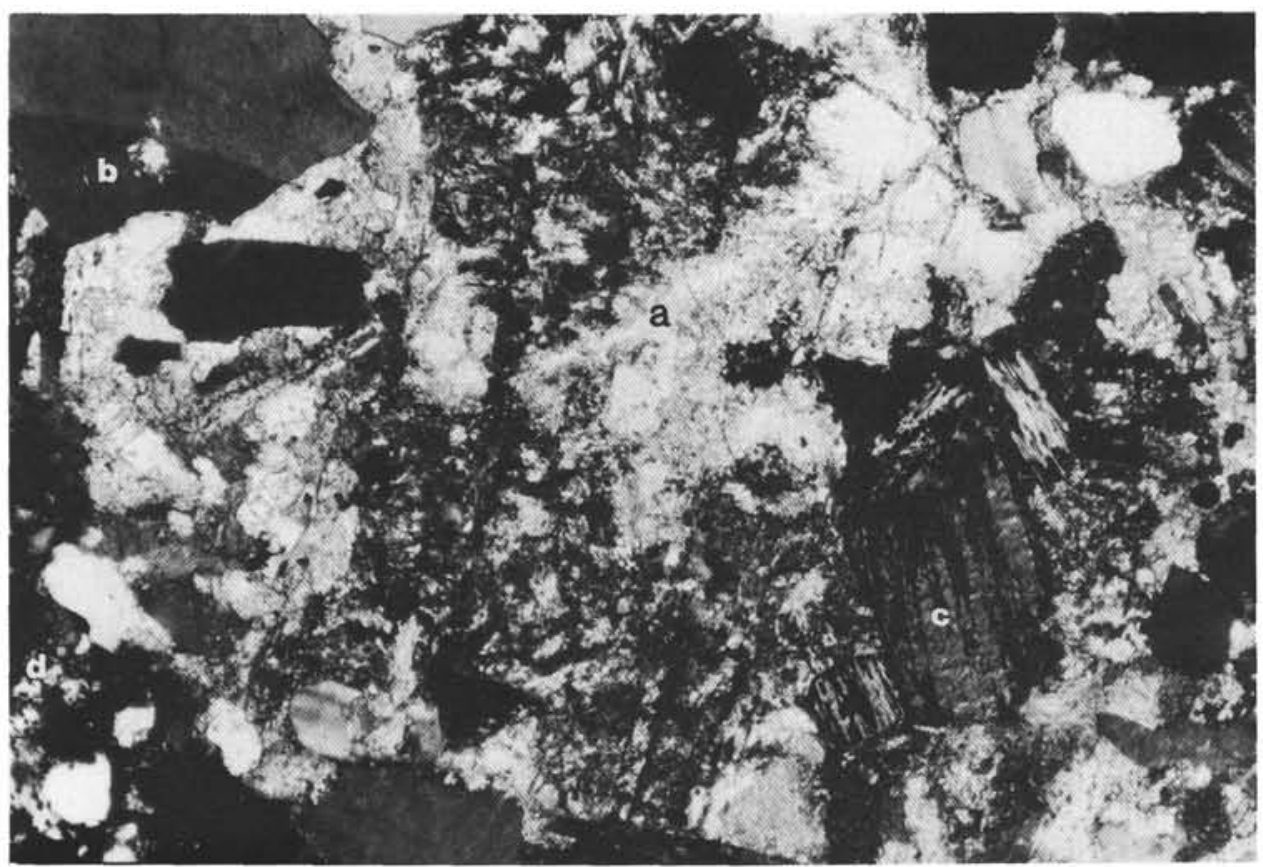

A

$0.50 \mathrm{~mm}$
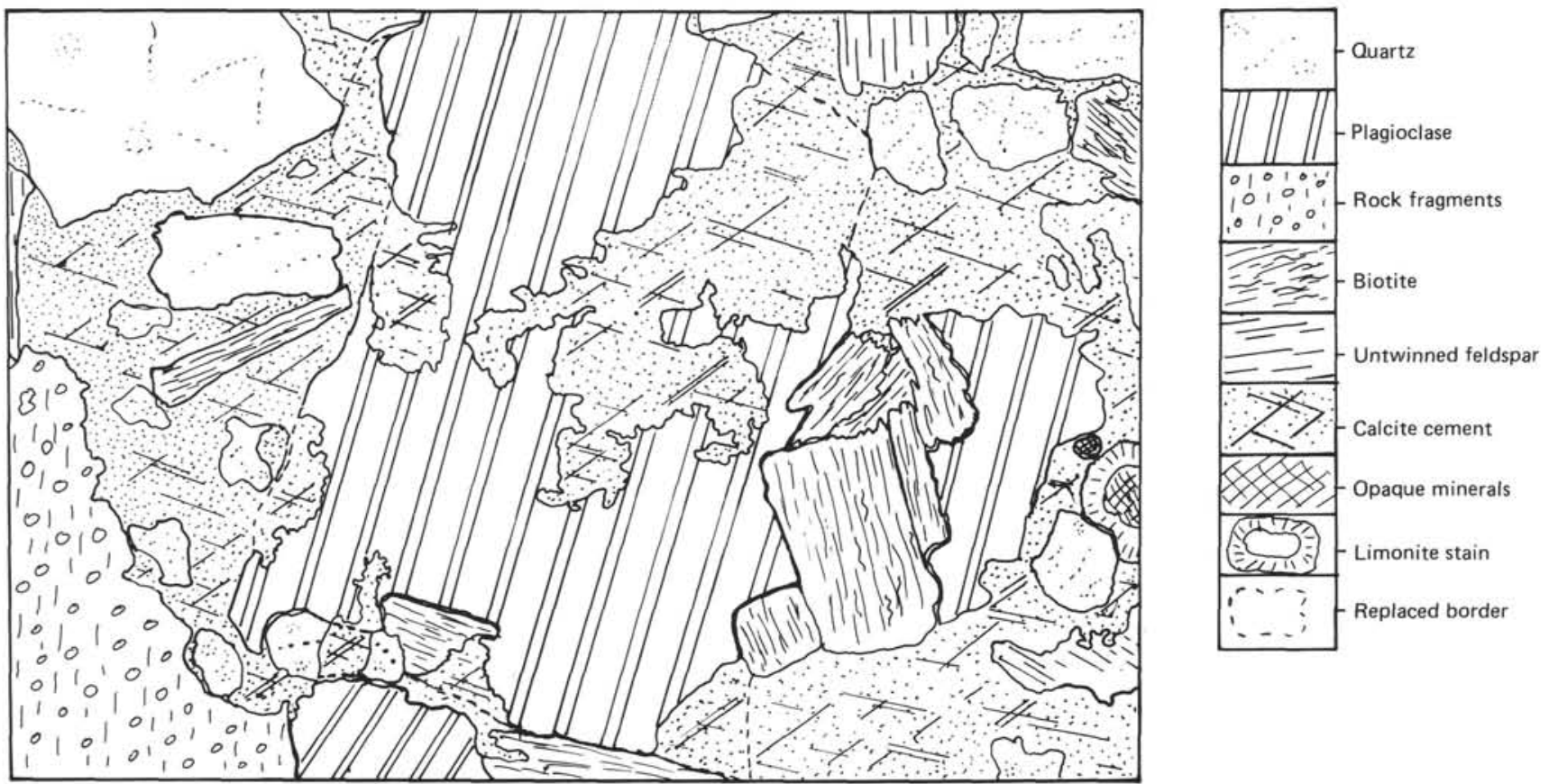

B

Figure 9. A. Photomicrograph of turbidite sandstone showing calcite replacement of large feldspar (a). Quartz grain (b) is slightly replaced at the edges, giving the grain an angular appearance. Other grains include very dark biotite (c) and a large metasedimentary rock fragment (d). Sample 103-638B-43R-1, 78-83 cm. B. Drawing of same field, showing replacing and cementing calcite.

Portugal (Fig. 13). The ridge is irregular in width, averaging about $60 \mathrm{~km}$, and is revealed even today in the bathymetry (Fig. 1). We will use the name Galicia Ridge for the extension of Galicia Bank south to Vasco da Gama Seamount.

\section{Structure and Stratigraphy of Galicia Ridge}

To interpret the subsurface structure and stratigraphy of Galicia Ridge, we use the multichannel seismic-reflection profiles obtained by the Institut Français du Pétrole (Pls. 1 and 2). The location of these profiles (GP-11, GP-101, GP-12, and GP102B1) is shown in Figure 3, and the corresponding interpretations of the profiles are shown as time sections on Figures 2A2D. Near Site 638 , the drill data permit us to correlate seismic units with lithologic units with fair confidence, but farther west the seismic stratigraphy below the base of the post-rift sediments is unclear, and we are more conservative there in our esti- 


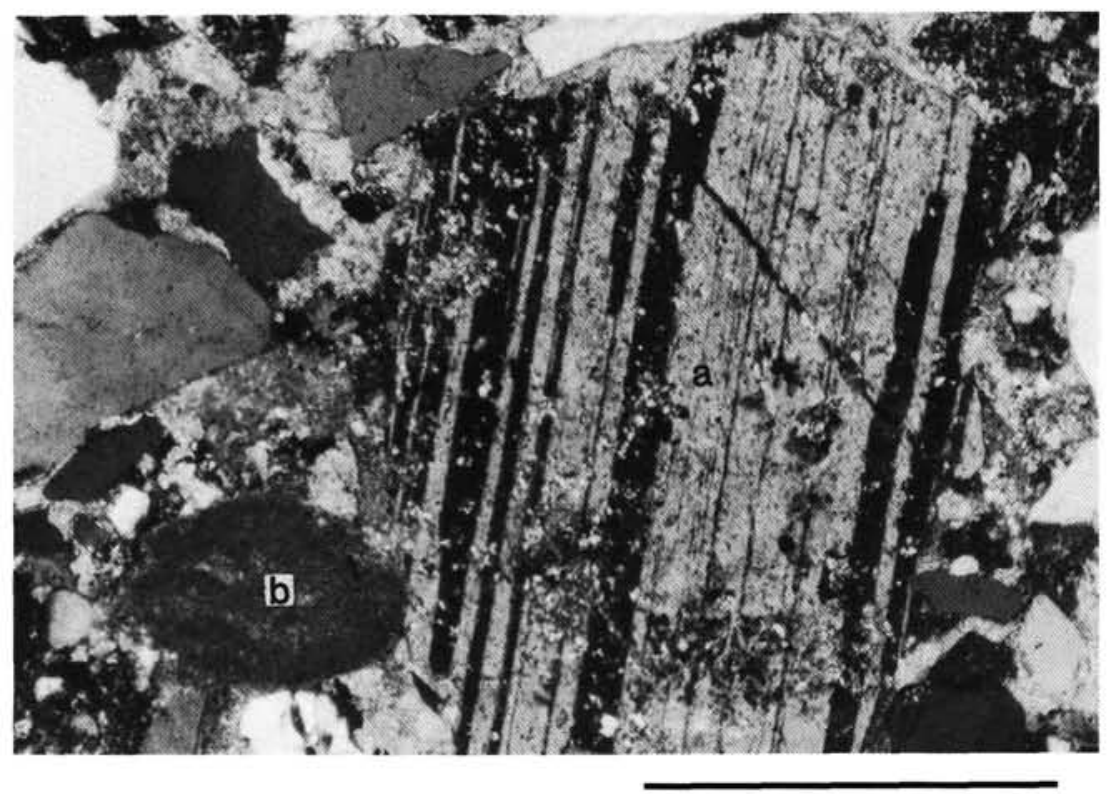

$0.50 \mathrm{~mm}$

Figure 10. Photomicrograph of calcite-cemented sandstone, showing incipient replacement of plagioclase (a) and a micritized carbonate peloid (b). Note the extensive replacement of grains in the upper left corner of the figure. Sample 103-638C-4R-2, 102-105 cm.

mates of the base of the rift sequence. From observations made from the submersible Nautile (Boillot et al., 1986), we know the position of the top of crystalline basement and of Jurassic platform carbonates along GP-11 (Fig. 2A), and we have used that control to estimate the top of basement elsewhere.

These profiles show that older (Valanginian-early Hauterivian age) rift-stage sediments belonging to seismic Unit 5 are absent beneath the flat summit of Galicia Ridge. Instead, post-rift (post-Aptian) sediments (seismic Units $1-3$ ) rest directly on either an acoustical basement that reveals no coherent internal reflections or on seismic Unit 4, which represents sediments deposited during the later stages of rifting (Hauterivian-Aptian). We interpret the acoustic basement as crystalline basement (perhaps locally including Jurassic carbonate-platform sediments).

West of Galicia Ridge and Galicia Bank, seismic profiles and drilling show that rift-stage sediments are again present in halfgrabens bounded by west-dipping normal faults, all the way to the continent/ocean boundary, between Sites 640 and 637. As shown on the bathymetric map (Fig. 1), some of these half-grabens extend northward from the area of Site 638 into the southwestern part of Galicia Bank, suggesting that the seaward part of the Bank may overlie rift-stage sediments.

We interpret these data to indicate that much of the area of Galicia Bank and Galicia Ridge remained structurally elevated during the early stages of rifting of the Galicia margin in the Early Cretaceous, and never received any Valanginian or lower Hauterivian sediments. On the contrary, the Bank and Ridge were themselves source areas for sandy and muddy sediments that poured westward (and perhaps eastward as well) in turbidity currents into the developing half-grabens.

\section{Dimensions}

The area of greater Galicia Bank (Fig. 1) is about $4000 \mathrm{~km}^{2}$, and the area of Galicia Ridge is about $8000 \mathrm{~km}^{2}$. Of this 12,000 $\mathrm{km}^{2}$ area, some part of it (say one-third to be conservative) probably drained eastward during Early Cretaceous times into the Interior Basin, leaving an estimated $8000 \mathrm{~km}^{2}$ to act as the source area for the Lower Cretaceous sediments west of the Bank and Ridge. We can now ask how much sediment was derived from this area.

\section{Volume of Unit 5}

To estimate the volume of rift sediments west of Galicia Bank and Ridge, we have interpreted the four good multichannel seismic profiles available to us by converting the time sections (Fig. 2 ) to depth sections. An example of one of these interpretations, of Profile GP-101, is shown in Figure 14. To convert the time sections to depth sections, we have taken into account the drilling and logging data from Legs 47B (Shipboard Scientific Party, 1979) and 103 (Boillot, Winterer, et al., 1987) and have used the following velocities of sound through the various stratigraphic units:

Units 1-3 (post-rift sediments)

Unit 4 (late rift-stage, Hauterivian-Aptian)

$2.0 \mathrm{~km} / \mathrm{s}$

Unit 5 (early rift-stage, Valanginian-Hauterivian)

Basement, including Jurassic carbonates

2.5

3.5

6.0

The true values for the rift-stage units may be somewhat higher than the values we have used because of additional compaction and cementation effects where the sediments are more deeply buried than at the Leg 103 drill sites. Our assumed values will yield thicknesses at the lower end of the range of reasonable figures.

For each of the depth sections, we calculate the total crosssectional area of rift-stage sediments, and then divide by the known length of the section to obtain the average thickness of rift sediments for that section. The results are as follows (in meters):

$\begin{array}{lccc}\quad \text { Profile } & \text { Seismic Unit 4 } & \text { Seismic Unit 5 } & \text { Total } \\ \text { GP-11 } & 137 & 691 & 828 \\ \text { GP-101 } & 238 & 542 & 780 \\ \text { GP-12 } & 118 & 513 & 631 \\ \text { GP-102B1 } & 194 & 537 & 731\end{array}$




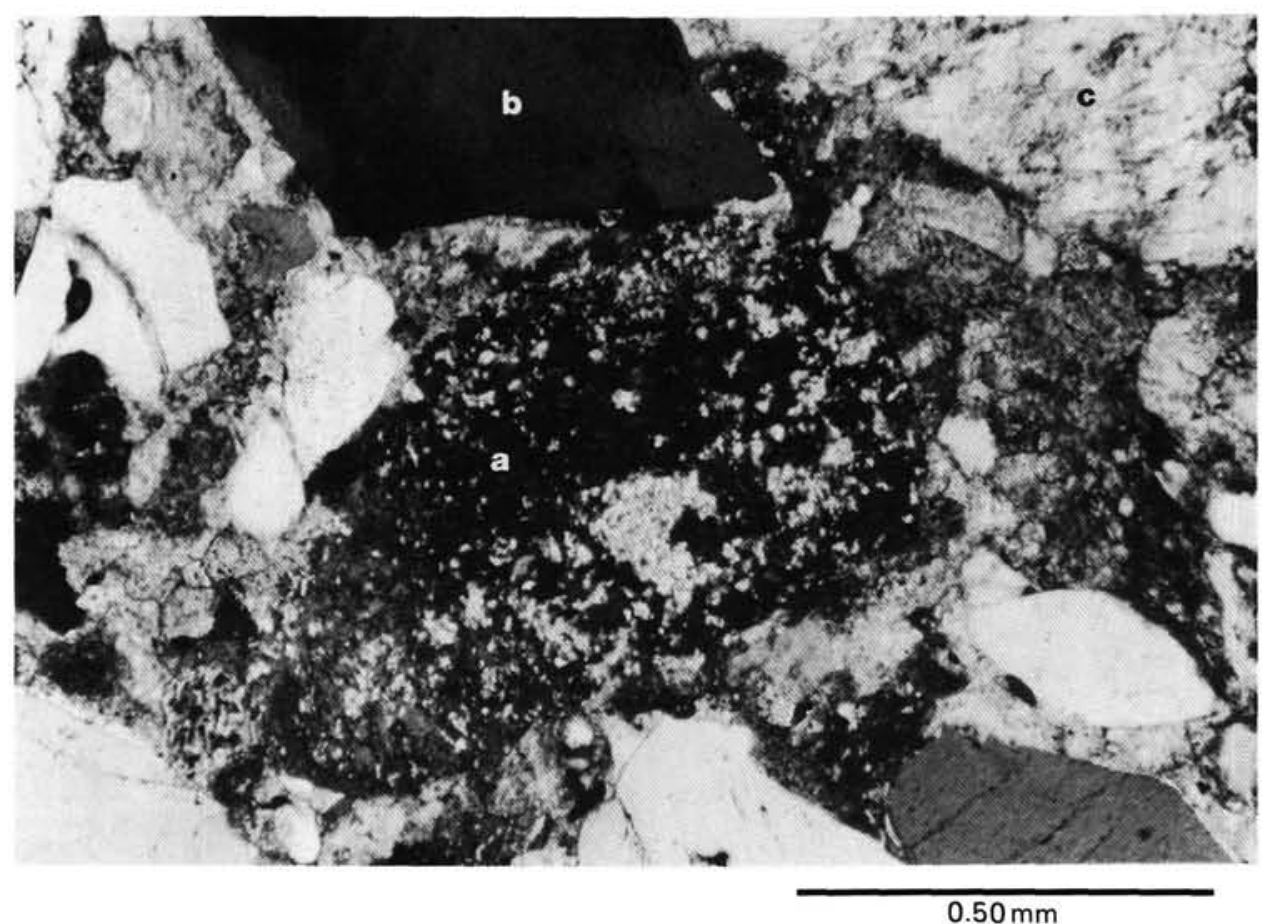

A

$0.50 \mathrm{~mm}$
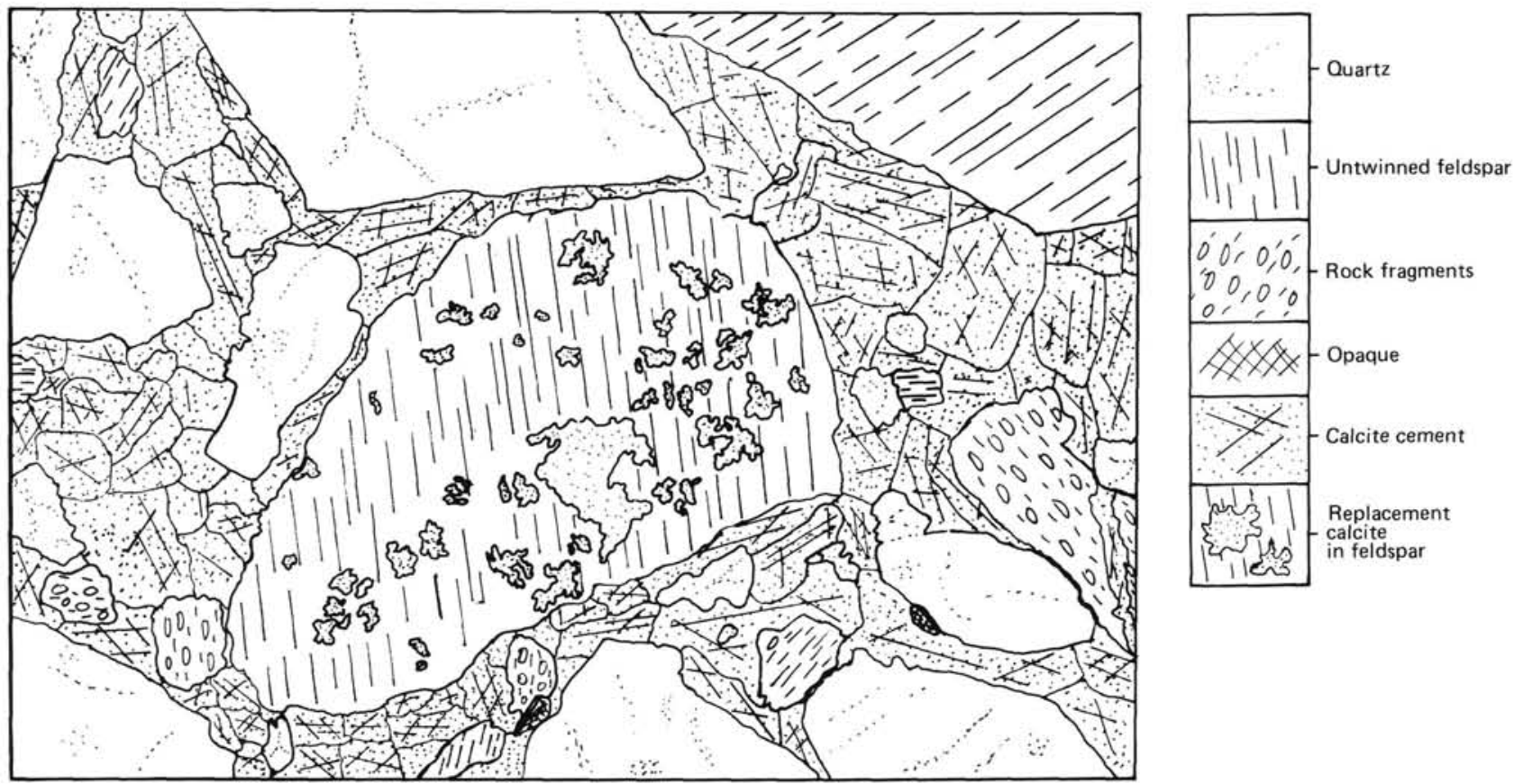

B

Figure 11. A. Photomicrograph of turbidite sandstone showing feldspar being replaced by calcite (a) whereas quartz (b) remains virtually unaffected. Another feldspar grain (c) shows signs of alteration. Sample 103-638B-43R-1, 78-83 cm. B. Drawing of same field, showing replacing and cementing relations.

The average is about $750 \mathrm{~m}$, which we will assume is typical for the entire margin immediately west of Galicia Bank and Ridge. About $75 \%$ of the total thickness is in Unit 5, the turbidite sandstone unit. Unit 5 has an average thickness of about $570 \mathrm{~m}$.

The part of the margin directly west of Galicia Bank and Galicia Ridge, not counting the triangular segment at the north end (Fig. 1), is about $160 \mathrm{~km}$ long, giving an area of about $13,000 \mathrm{~km}^{2}$. The total volume of rift sediments on this part of the margin is thus about $10,000 \mathrm{~km}^{3}$, and the volume assignable to Unit 5 is about $7400 \mathrm{~km}^{3}$.

\section{Erosion Rates}

To derive the mass of sandy sediments represented in seismic Unit 5 from the estimated $8000-\mathrm{km}^{2}$ drainage area of Galicia Bank and Ridge, assuming that $1 \mathrm{~km}^{3}$ of source rock yields 1 $\mathrm{km}^{3}$ of sediment (i.e., no solids escape from the system and the losses by dissolution of bed rock are matched by the porosity of 


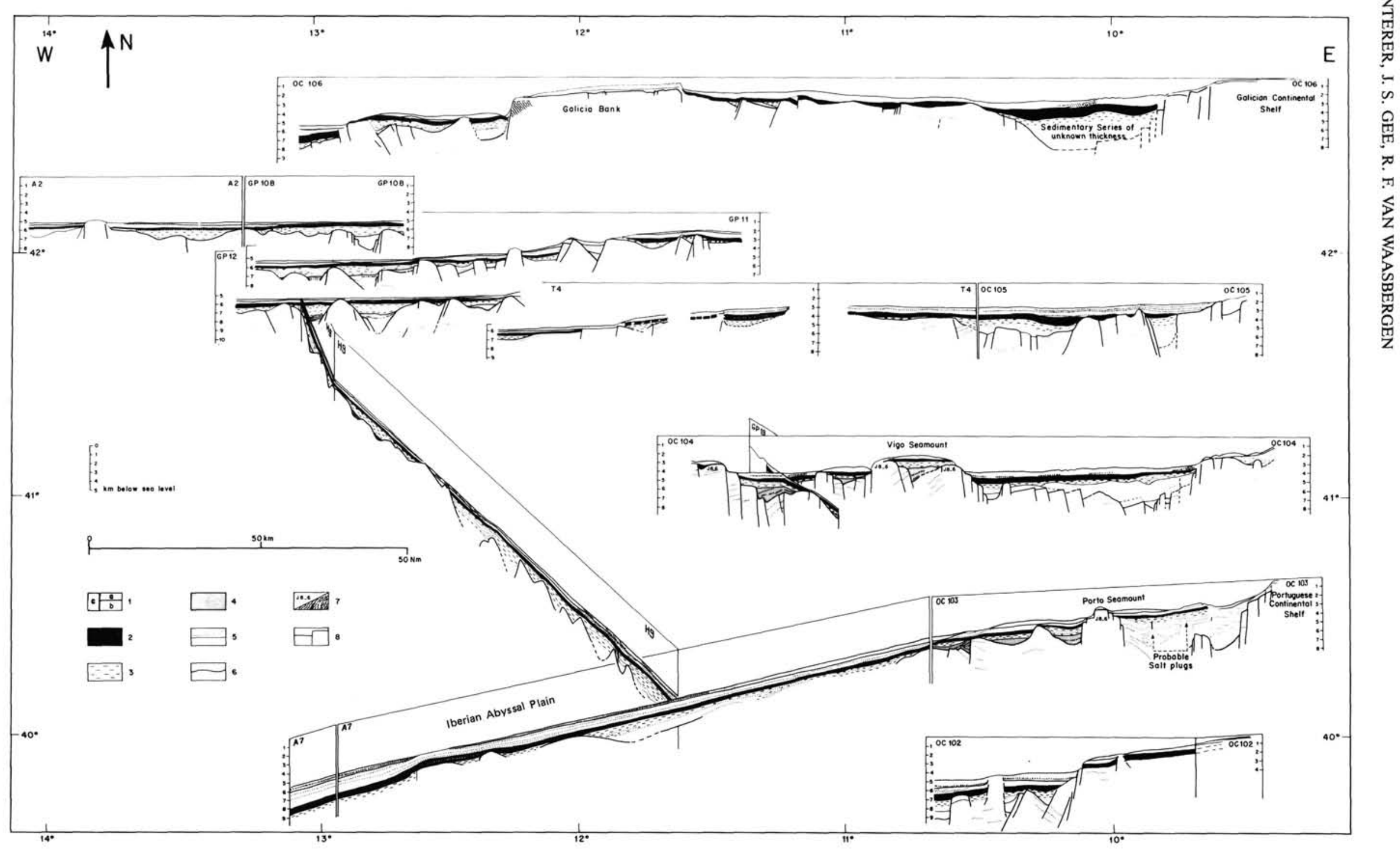

Figure 12. Seismic-reflection profiles on the Galicia margin. For interpretation, see Groupe Galice (1979, p. 642). 


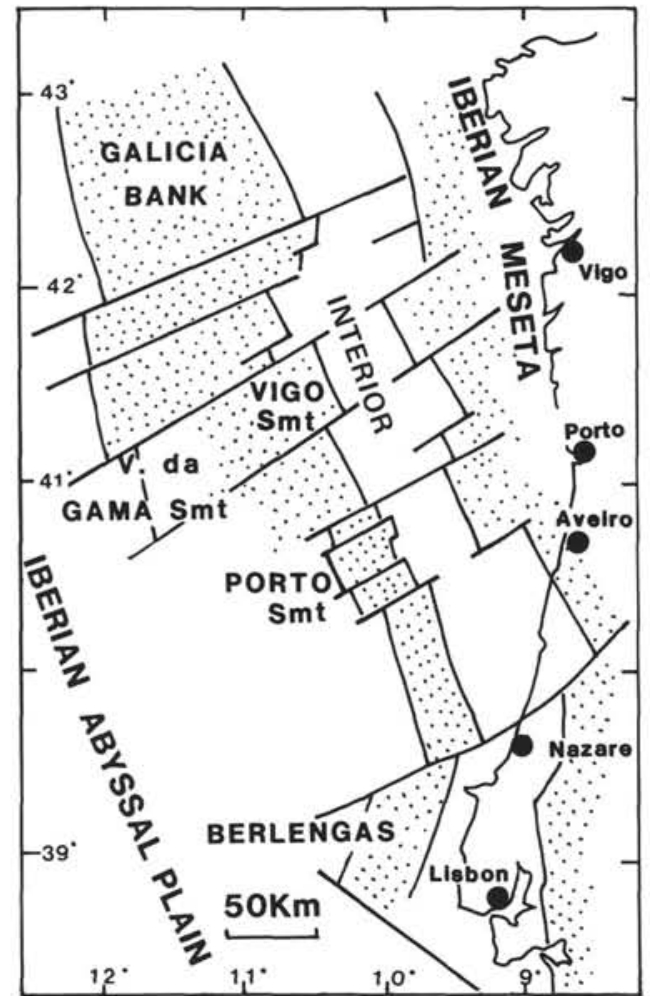

Figure 13. Schematic arrangement of major fault-controlled highs (stippled) and basins along the western side of Iberia during the Triassic and Jurassic. The Interior Basin is shown as a prolongation of the Lusitanian Basin (from Montenat et al., this volume).

the sediments), requires erosion of a block of crystalline bed rock with an average thickness of $925 \mathrm{~m}$. For seismic Unit 4, erosion of a block about $325 \mathrm{~m}$ thick is calculated. Even this figure is an overestimate, given the proportion of biogenic pelagic material in Unit 4, which we estimate from data in the site chapters (Boillot, Winterer, et al., 1987) as 30\%-50\%.

To estimate an average rate of erosion of the source area, we take the time of accumulation of Unit 5, the sandy turbidite unit, as about 5 m.y., from late Valanginian to early Hauterivian time. The corresponding average rate of erosion for the source area over this time interval is about $185 \mathrm{~m} / \mathrm{m} . \mathrm{y}$. (18.5 $\mathrm{cm} / 1000 \mathrm{yr}$ ). This rate, judging by the trends in thickness and grain size of turbidite sands at Site 638 (Boillot, Winterer, et al., 1987), was probably even greater in the early part of this time interval, and tailed off to a much lower value when deposition of Unit 4 began. There was an exponential decrease in sedimentation rates at Sites 638 and 641 over the $20 \mathrm{~m}$.y. of rift-stage sedimentation, from rates greater than $50 \mathrm{~m} / \mathrm{m}$.y. in the Valanginian, to about $20 \mathrm{~m} / \mathrm{m}$.y. in the early Hauterivian, to only 5 $\mathrm{m} / \mathrm{m}$.y. in the Aptian, accompanied by a decrease in the ratio of siliciclastic to biogenic material (Boillot, Winterer, et al., 1987), and we suppose that erosion rates in the source area declined apace with the decline in clastic sedimentation rates.

\section{Climate and Relief}

Rates of erosion are a complex function of relief, climate, and rock type, but erosion rates on the order of $200 \mathrm{~m} / \mathrm{m}$.y. do suggest considerable relief. For comparison, drainage basins of about $10,000-\mathrm{km}^{2}$ area in coastal Southern California, where the total relief is about $2000 \mathrm{~m}$, the climate is Mediterranean, and the bed rock in the mountains is mainly crystalline rocks, have erosion rates of about $130 \mathrm{~m} / \mathrm{m} . \mathrm{y}$. (Moore, 1969). Comparable rates are documented from drainage basins of similar size and relief in Northern California, where the rainfall is several times greater (Judson and Ritter, 1964). The Early Cretaceous Galicia Bank region was probably somewhat wetter than modern Southern California and warmer on the average than Northern California, as evidenced not only by the abundant terrestrial plant debris in the Lower Cretaceous sandstone beds of Unit 5 (Fig. 15), including ferns, but also by the regional paleobotani$\mathrm{cal}$ and sedimentological data from correlative Wealden beds in the south of England, which indicate a mild $\left(20^{\circ}-25^{\circ} \mathrm{C}\right)$, somewhat humid (rain more than $1000 \mathrm{~mm} / \mathrm{yr}$ ) climate (Sladen and Batten, 1984). Galicia Bank had a latitude about $5^{\circ} \mathrm{S}$ of the south coast of England during the Early Cretaceous, i.e., about $25^{\circ} \mathrm{N}$ of the equator (Dercourt et al., 1986). We suggest that the coastal mountains of eastern Cuba or the island of New Caledonia may be a plausible modern analogue, in terms of climate and relief, for the little chain of fault-block mountains-the Galicia Hills-that stood over the present site of Galicia Bank and Ridge during part of Early Cretaceous times.

\section{TECTONIC IMPLICATIONS}

\section{Uplift}

The pre-Valanginian tectonic history of the Galicia Hills is open to interpretation. The coarse fluvial sandstone interval in the Upper Jurassic at Site 639 (Boillot, Winterer, et al., 1987) suggests nearby relief, and the overlying platform limestone and dolomite and deep-water marlstone indicate that coarse clastics ceased to reach the drill site for several million years, either because the Galicia Hills were drowned or because clastics from them were diverted away from the drill site, most likely into basins created by incipient crustal thinning.

The sudden influx of Valanginian clastics suggests accompanying uplift in the source area, and poses the problem of explaining uplift in a region of general crustal thinning and subsidence. We suggest that in the simple-shear model of the continental lithosphere (Wernicke, 1985) applied to the Galicia margin to explain the ridge of peridotite along the ocean/continent boundary (Boillot et al., 1987), a west-dipping shear zone emerged near the west ridge of the Galicia Hills block (i.e., that the fault near shotpoint 3600 on Figure 14, on the west side of the Hills, was a "breakaway" fault; Fig. 16). The Galicia Hills would have been uplifted by the isostatic rebound of the crust resulting from rapid tectonic unloading (sliding away) of crust west of the breakaway (Wernicke, 1985). Under this hypothesis, the Interior Basin, between the Galicia Hills and the Iberian mainland, belonged to a separate tectonic unit, with its own history of subsidence.

An alternate model, with an east-dipping simple shear, is presented in this volume by Boillot et al. In their model, the Galicia margin is the hanging-wall block above the shear, and thermal uplift, reaching a maximum where the crust thickens to normal continental values, as at Galicia Bank, is predicted in the analysis of Buck et al. (1988).

\section{Lowering and Drowning}

The data from drilling at Sites 638 and 641 (Boillot, Winterer, et al., 1987) show that although sedimentation rates declined in Hauterivian times and thereafter, the Galicia Hills continued for another $15 \mathrm{~m}$.y. to supply quartzo-feldspathic silt and clay to the fault-block basins offshore. In the late Barremian, shallow-water carbonate reefs established themselves along the perimeter of the Hills in the area of present-day Galicia Bank, and these reefs flourished until nearly the close of the Aptian. Carbonate detritus from the reefs moved seaward in turbidity 


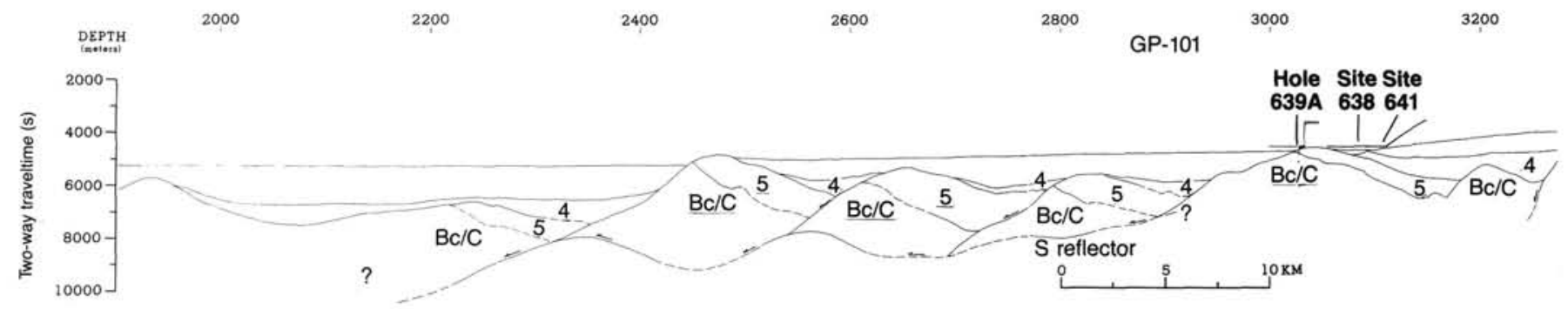

Figure 14. Geologic cross section along Line GP-101 derived from the seismic profile shown on Figure 2B. Velocities used are given in text. Horizontal scale: 100 shotpoints $=5 \mathrm{~km}$. Vertical scale in meters.

Flemish Cap

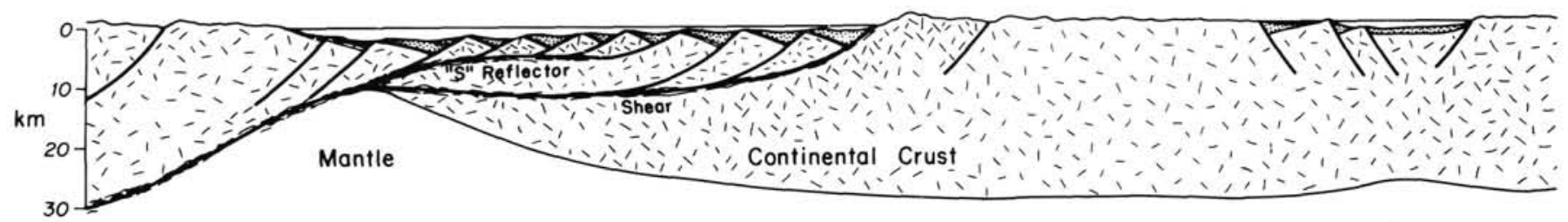

Figure 16. Schematic east-west cross section (no vertical exaggeration) of the Galicia margin at about $42^{\circ} 10^{\prime} \mathrm{N}$, during deposition of seismic Unit 5 at about the end of Valanginian time, prior to the separation of North America from Iberia. Based on seismic-reflection data, using the simple-shear model of Wernicke (1985) as applied to the Galicia margin by Boillot et al. (1987). A west-dipping shear cutting through the continental crust forms a breakaway scarp at the edge of the Galicia Hills. The sliding away of listric fault blocks unloads the crust, allowing isostatic rebound and uplift of the western part of the Hills. Rapid erosion of the newly created relief supplies coarse clastics to the fault-block basins to the west. The upper, subsidiary shear beneath the western fault blocks is the S reflector seen on seismic records across the margin (Pls. 1 and 2 and Figs. 2 and 14). The crust thins westward toward the rising ridge of mantle material marking the site where a ridge of peridotite crops out today, at the continent/ocean boundary. A layer of Upper Jurassic shallow-water carbonates and sandstone underlies the deep-water Valanginian clastics between Flemish Cap and the Galicia Hills, and pre-Valanginian sediments are believed to be present in the Interior Basin, between the Galicia Hills and the Iberian mainland. The basic simple-shear geometry, extending from the Galicia margin beneath the Grand Banks, was first suggested to us by A. J. Tankard (pers. comm., 1985).

currents and debris flows along with clay and silt, into deep water, guided partly by the fault-controlled seafloor topography. By the end of Aptian time, when seafloor spreading began in the adjacent Atlantic, no more reef detritus was being incorporated in basinal sediments, and we take this as evidence that the reefs had drowned, possibly because of a eustatic rise in sea level that affected reefs a half a world away (Winterer and Metzler, 1984).

Drowning of the southern part of the Galicia Hills began during Hauterivian and Barremian time, as shown on the seismic profiles (Fig. 2) by the widespread occurrence of seismic Unit 4 on the Hills. In some places low knobs of basement protruded through the sediment blanket, but in the absence of knowledge about the depth facies of Unit 4 in this area we cannot say whether these knobs stood above sea level to serve as sediment sources.

The reduction of most of the Galicia Hills to sea level over the time span of 20 m.y. requires crustal thinning by extension or thermal contraction of the lithosphere in addition to surficial erosional processes. The fluvial erosion of a landmass to a nearly flat surface near sea level takes an exceedingly long time: it is essentially an asymptotic process. Not only are rates of erosion slowed as relief is lowered, but isostasy tends partly to restore relief as it is lost. Using a simple Airy isostatic model for erosional unloading of the source area (mantle density, 3.3 $\mathrm{g} / \mathrm{cm}^{3}$; crustal density, $2.65 \mathrm{~g} / \mathrm{cm}^{3}$ ), each $100 \mathrm{~m}$ of erosional lowering is partly compensated by about $80 \mathrm{~m}$ of isostatic uplift. The erosional removal of a thickness of $925 \mathrm{~m}$ of bedrock from the Galicia Hills, as estimated in the preceding discussion of sediment volumes, would be compensated by about $740 \mathrm{~m}$ of isostatic uplift, resulting in a net loss of only about $185 \mathrm{~m}$ of height above sea level. If (1) we assume that the Galicia Hills were originally perhaps about 1000 or $1500 \mathrm{~m}$ high at the drainage divide, a height consistent with the high erosion rates estimated for Valanginian time, and if (2) we admit that the big decline in erosion rates that followed accumulation of the sandy turbidites during those first $5 \mathrm{~m}$.y. indicates that most of the original relief in the source area had already been removed, then we must call on more than erosional processes to lower the landscape. If only about one-fifth of the total lowering can be ascribed to erosion alone, we must consider that the rest was due to crustal thinning.

The amount of crustal thinning called for is modest. To reduce, say, $1 \mathrm{~km}$ of height down to sea level takes about $5 \mathrm{~km}$ of thinning. We suppose that the mechanism for this thinning was the same as that proposed for the rest of the margin, namely extension of the crust by listric faulting in the upper, more brittle levels and by ductile deformation in the lower levels (Boillot et al., 1986). Adding the effects of the two processes, erosional and extensional, the net result was an estimated loss of about 6 $\mathrm{km}$ of crustal thickness during the $5 \mathrm{~m}$.y. it took to deposit the turbidite sandstone of Unit 5 .

\section{CONCLUSIONS}

To return to the questions posed in the introduction:

1. Where was the source area? The source area for the Lower Cretaceous clastic sediments on the rifted continental margin west of Galicia Bank was the Bank itself and its southern extension. Sediments eroded from the Iberian mainland were trapped in the Interior Basin, between the mainland and Galicia Bank.

2. What were its areal dimensions and height? The westward-draining part of the source area was roughly $60 \mathrm{~km}$ wide 


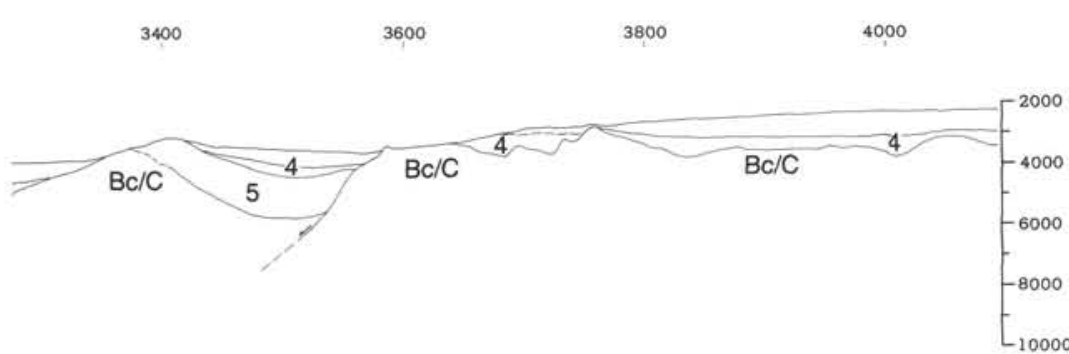

Figure 14 (continued).

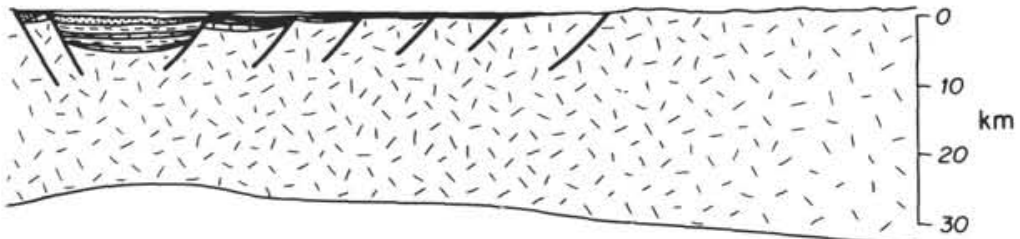

Figure 16 (continued).

and $200 \mathrm{~km}$ long, and may have had an altitude, along the crest of the highlands, of about $1000-1500 \mathrm{~m}$.

3. What were the roles of tectonism and isostasy in creating and maintaining relief? The relatively small size of the source area and the great volume of sediments derived from it imply deep erosion. To create the relief necessary for the rapid erosion rates indicated by high clastic sedimentation rates implies tectonic uplift of the source area in the Valanginian by thermal uplift or isostatic rebound from tectonic unloading during the initial stages of continental stretching and rifting. Following initial uplift, the crust continued to cool and/or thin, partly by listric faulting, and this resulted in subsidence of the source area. Isostatic rebound during erosion probably helped to slow the net rate of subsidence, and thereby to stretch out the survival time of hilly topography. Nonetheless, through continued but gradually slowing subsidence and erosion, nearly all of the source area was reduced to sea level by the end of the Aptian, about the time when seafloor spreading began in the adjacent Atlantic.

4. What was the geology of the source area? Fresh crystalline rocks, including plutonic rocks of granitic composition and quartz-mica schist, were widely exposed in the source area. At first, the mountains supplied coarse sand and mud derived chiefly from these crystalline rocks to the sea, but after a few million years of subsidence and erosion, the low-gradient streams supplied only mud. In the late Barremian and Aptian, carbonate banks flourished in the shallow waters along the margins of the source area and may have completely blanketed some parts of it.

5. What was its climate? The regional climate, judging by regional floral and sedimentological data for the nonmarine Lower Cretaceous Wealden sediments, was warm and humid. The source area was heavily forested, as evidenced by the abundant fragmental plant remains seen in cores from the adjacent sedimentary basins.

\section{ACKNOWLEDGMENTS}

Work on this paper was supported under a National Science Foundation Graduate Fellowship for J. Gee and by funds granted by the U.S. Science Advisory Committee to E. Winterer. We thank A.H.F. Robert-

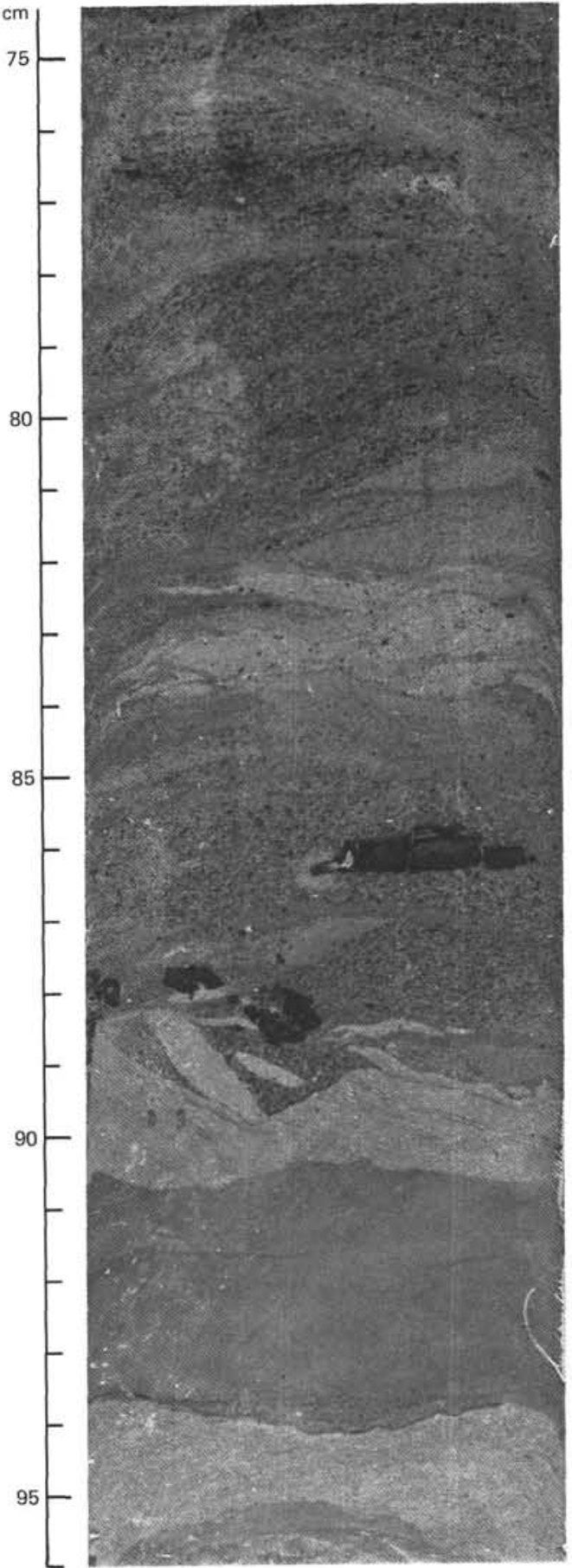

Figure 15. Angular fragments of fossilized plants in turbidite grains in the sandstone. Sample 103-638B-35R-4, 75-96 cm.

son and an anonymous reviewer for their constructive criticism of the draft version of the manuscript.

\section{REFERENCES}

Allen, P., 1969. Lower Cretaceous sourcelands and the North Atlantic. Nature, 222:657-658.

1972. Wealden detrital tourmaline: implications for northwestern Europe. J. Geol. Soc. (London), 128:273-294.

1981. Pursuit of Wealden models. J. Geol. Soc. (London), $138: 375-405$. 
Amiot, M., Floquet, M., Mathey, B., Pascal, A., Rat, P., and Salomon, J. 1982. Evolution de la marge cantabrique et son arrière-pays iberique au Crétacé. Cuad. Geol. Iber., 8:37-63.

Basu, A. 1976. Petrology of Holocene fluvial sand derived from plutonic source rocks: implications to paleoclimatic interpretation. $J$. Sediment. Petrol., 46:694-709.

Boillot, G., Comas, M., Girardeau, J., Kornprobst, J., Loreau, J-P., Malod, J., Mougenot, D., and Moullade, M., 1986. Fonds sousmarins basaltiques et ultramafiques au pied d'une marge stable. Résultats préliminaires de la campagne Gaulinaute (plongées du submersible Nautile à 1' ouest de Espagne. C. R. Acad. Sci. Ser. 2, 303: 1719-1724

Boillot, G., Recq, M., Winterer, E. L., Meyer, A. N., Applegate, J., Baltuck, M., Bergen, J. A., Comas, M. C., Davies, T. A., Dunham, K., Evans, C. A., Girardeau, J., Goldberg, D. G., Haggerty, J., Jansa, L. F., Johnson, J. A., Kasahara, J., Loreau, J.-P., Luna-Sierra, E., Moullade, M., Ogg, J., Sarti, M., Thurow, J., and Williamson, M., 1987. Tectonic denudation of the upper mantle along passive margins: a model based on drilling results (ODP Leg 103, western Galicia margin, Spain). Tectonophysics, 132:335-342.

Boillot, G., Winterer, E. L., et al., 1987. Proc. ODP, Init. Repts., 103: College Station, TX (Ocean Drilling Program).

Buck, W. R., Martinez, F., Steckler, M. S., and Cochran, J. R., 1988. Thermal consequences of lithospheric extension: pure and simple. Tectonics, 7:213-234:

Dercourt, J., Zonenshain, L. P., Ricou, L. E., Kazmin, V. G., Le Pichon, X., Kipper, A. L., Grandjaquet, C., and Sbortshikov, I. M., 1986. Geological evolution of the Tethys belt from the Atlantic to the Pamirs since the Lias. Tectonophysics, 123:241-315.

Groupe Galice, 1979. The continental margin off Galicia and Portugal: acoustical stratigraphy, dredge stratigraphy, and structural evolution, In Sibuet, J.-C., Ryan, W.B.F., et al., Init. Repts. DSDP, 47, Pt. 2: Washington (U.S. Govt. Printing Office), 633-662.

Judson, S., and Ritter, D. F., 1964. Rates of regional denudation in the United States. J. Geophys. Res., 69:3395-3401.

Julivert, M., Fontboté, J. M., Ribeiro, A., and Conde, L., 1977. Mapa Tectonico de la Peninsula Iberica y Baleares. Madrid (Inst. Geol. Minero Esp.).

Lancelot, Y., and Winterer, E. L., 1980. Evolution of the Moroccan oceanic basin and adjacent continental margin-a synthesis. In Lancelot, Y., Winterer, E. L., et al., Init. Repts. DSDP, 50: Washington (U.S. Govt. Printing Office), 801-821.

Mattick, R. E., Schlee, J. S., and Bayer, K. C., 1982. The geology and hydrocarbon potential of the Georges Bank-Baltimore Canyon Trough area. In Kerr, J. W., Fergusson, A. J., and Machan, L. C. (Eds.), Geology of the North Atlantic Borderlands: Mem. Can. Soc. Pet. Geol., 7:461-486.

McWhae, J. R., 1982. Structure and spreading history of the northwestern Atlantic region from the Scotian Shelf of Baffin Bay. In Kerr, J. W., Fergusson, A. J., and Machan, L. C. (Eds.), Geology of the North Atlantic Borderlands: Mem. Can. Soc. Pet. Geol., 7:299-332.

Montadert, L., de Charpal, O., Roberts, D., Guennoc, P., and Sibuet, J., 1979. Northeast Atlantic passive margins: rifting and subsidence processes. In Talwani, M., Hay, W., and Ryan, W.B.F. (Eds.), Deep Drilling Results in the Atlantic Ocean: Continental Margins and Paleoenvironment: Am. Geophys. Union, Maurice Ewing Ser., 3:154156.

Moore, D. G., 1969. Reflection profiling studies of the California continental borderland: structure and Quaternary turbidite basins. Spec. Pap. Geol. Soc. Am., 107:1-142.
Poag, C. W., 1982. Stratigraphic reference section for Georges Bank Basin- depositional model for New England passive margin. AAPG Bull., 66:1021-1041.

Pujalte, V., 1982. La evolucion paleogeografica de la cuenca "wealdense" de Cantabria. Cuad. Geol. Iber., 8:65-83.

Réhault, J.-P., and Mauffret, A., 1979. Relationships between tectonics sedimentation around the northwestern Iberian margin. In Sibuet, J.-C., Ryan, W.B.F., et al., Init. Repts. DSDP, 47, Pt. 2: Washington (U.S. Govt. Printing Office), 663-681.

Robertson, A.H.F., and Bernoulli, D., 1982. Stratigraphy, facies and significance of Late Mesozoic and Early Tertiary sedimentary rocks of Fuerteventura (Canary Islands) and Maio (Cape Verde Islands). In von Rad, U., Hinz, K., Sarnthein, M., and Seibold, E. (Eds.), Geology of the Northwest African Continental Margin: Berlin (Springer), 489-525.

Sabas, F. A., 1966. Mapa Geologica de la Peninsula Iberica Baleares y Canarias: Madrid (Inst. Geol. Minero Esp.).

Sarti, M., and von Rad, U., 1987. Early Cretaceous turbidite sedimentation at DSDP Site 603, off Cape Hatteras. In van Hinte, J., Wise, S. W., et al., Init. Repts. DSDP, 93: Washington (U.S. Govt. Printing Office), 891-940.

Shipboard Scientific Party, 1979. Site 398. In Sibuet, J.-C., and Ryan, W.B.F., Init. Repts. DSDP, 47, Pt. 1: Washington (U.S. Govt. Printing Office), 25-233.

Sladen, C. P., and Batten, D. J., 1984. Source-area environments of Late Jurassic and Early Cretaceous sediments in Southeast England. Proc. Geol. Assoc., 95:149-163.

von Rad, U., and Sarti, M., 1986. Early Cretaceous "events" in the evolution of the eastern and western North Atlantic continental margins. Geol. Rundsch., 75:139-158.

Wernicke, B., 1985. Uniform-sense normal simple shear of the continental lithosphere. Can. J. Earth Sci., 22:108-125.

Wiedmann, J., Butt, A., and Einsele, G., 1982. Cretaceous stratigraphy, environment, and subsidence history at the Moroccan continental margin. In von Rad, U., Hinz, K., Sarnthein, M., and Seibold, E. (Eds.), Geology of the Northwest African Continental Margin: Berlin (Springer), 366-395.

Wilson, R.C.L., 1975. Atlantic opening and Mesozoic continental margin basins of Iberia. Earth Planet. Sci. Lett., 25:33-43.

Wilson, R.C.L., and Exton, J., 1979. Mesozoic development of the Lusitanian Basin, West-Central Portugal. In Wilson, R.C.L., and Exton, J. (Eds.), Excursion to the Mesozoic of the Lusitanian Basin, West-Central Portugal, Pt. II: Dept. Earth Sci., Open Univ., 45-77.

Winterer, E. L., and Hinz, K., 1984. The evolution of the Mazagan continental margin: a synthesis of geophysical and geological data with results of drilling during Deep Sea Drilling Project Leg 79. In Hinz, K., and Winterer, E. L., Init. Repts. DSDP, 79, Washington (U.S. Govt. Printing Office), 893-919.

Winterer, E. L., and Metzler, C. V., 1984. Origin and subsidence of guyots in Mid-Pacific Mountains. J. Geophys. Res., 89:9969-9979.

Ziegler, P. A., 1982. Geological Atlas of Western and Central Europe: Amsterdam (Elsevier), 130.

Date of initial receipt: 23 February 1987

Date of acceptance: 31 July 1987

Ms 103B-181 


\section{Profile GP-11}

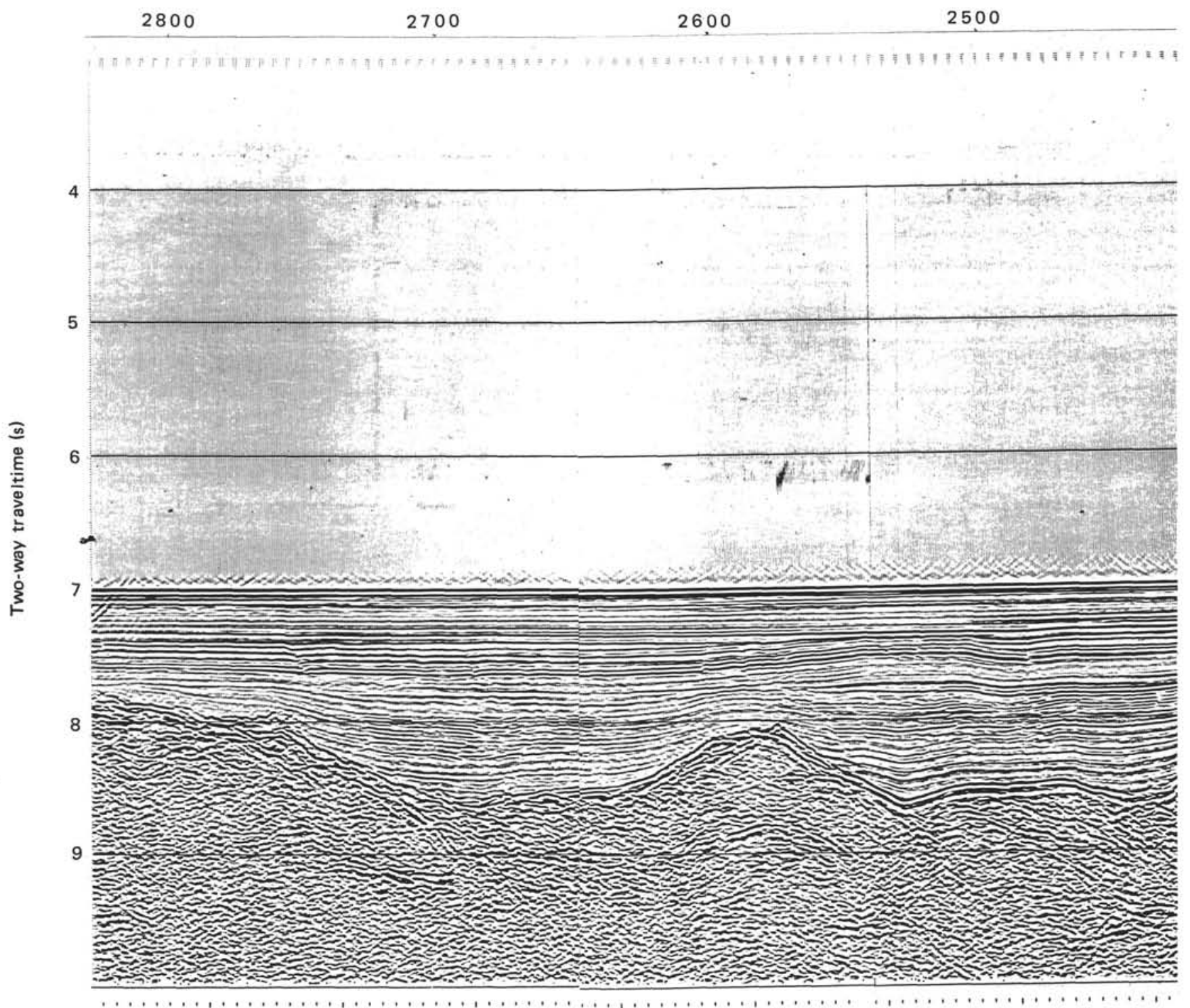

Plate 1. Seismic reflection profiles of the Galicia margin in the vicinity of the Leg 103 drill sites. The location of the profiles is shown in Figure 3. The profiles were made by the Institut Français du Pétrole and made available through Dr. L. Montadert. 1. Profile GP-11. 2. Profile GP-12. 3. Profile GP-102B1. 


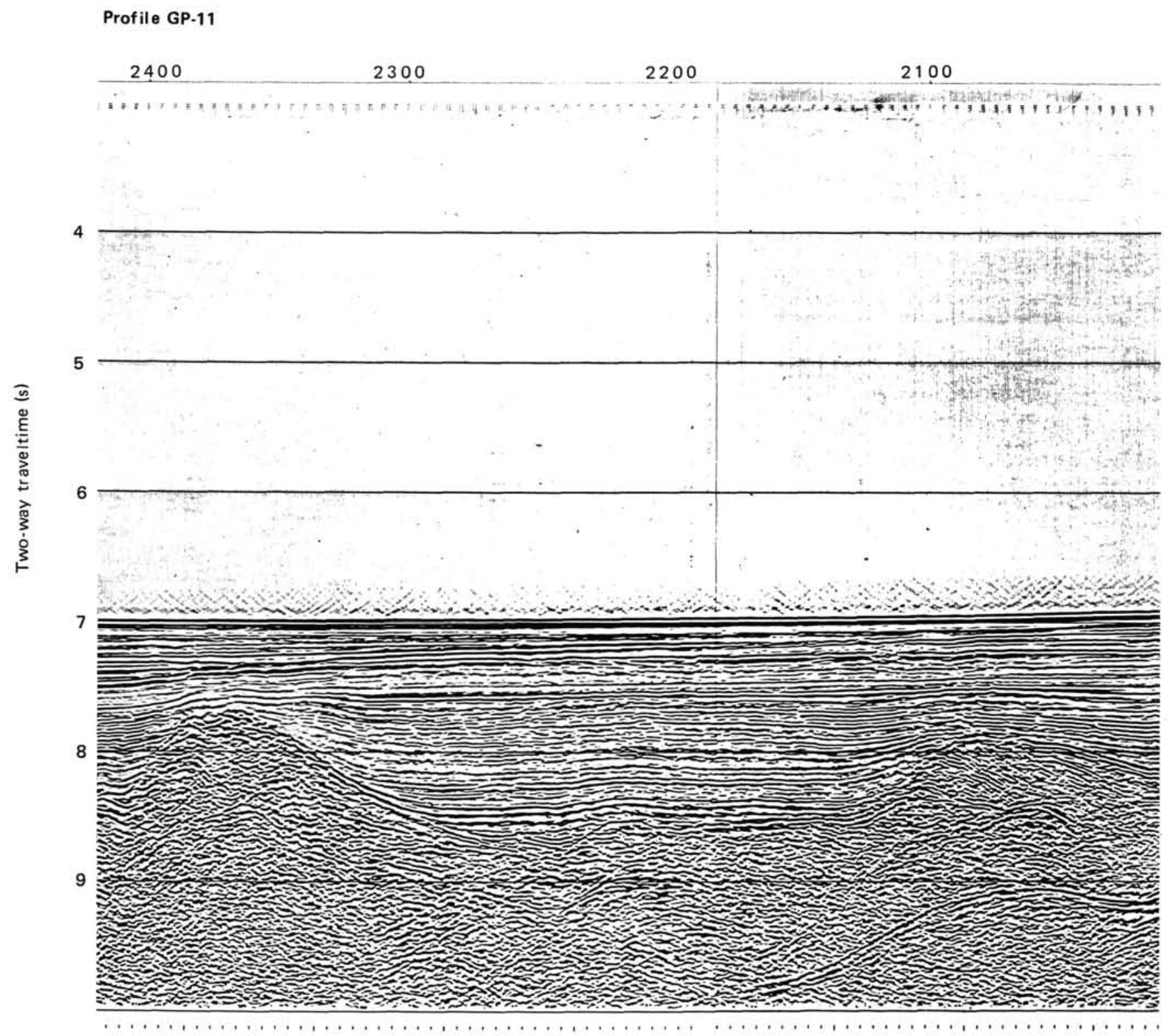

Plate 1 (continued). 
Profile GP-11

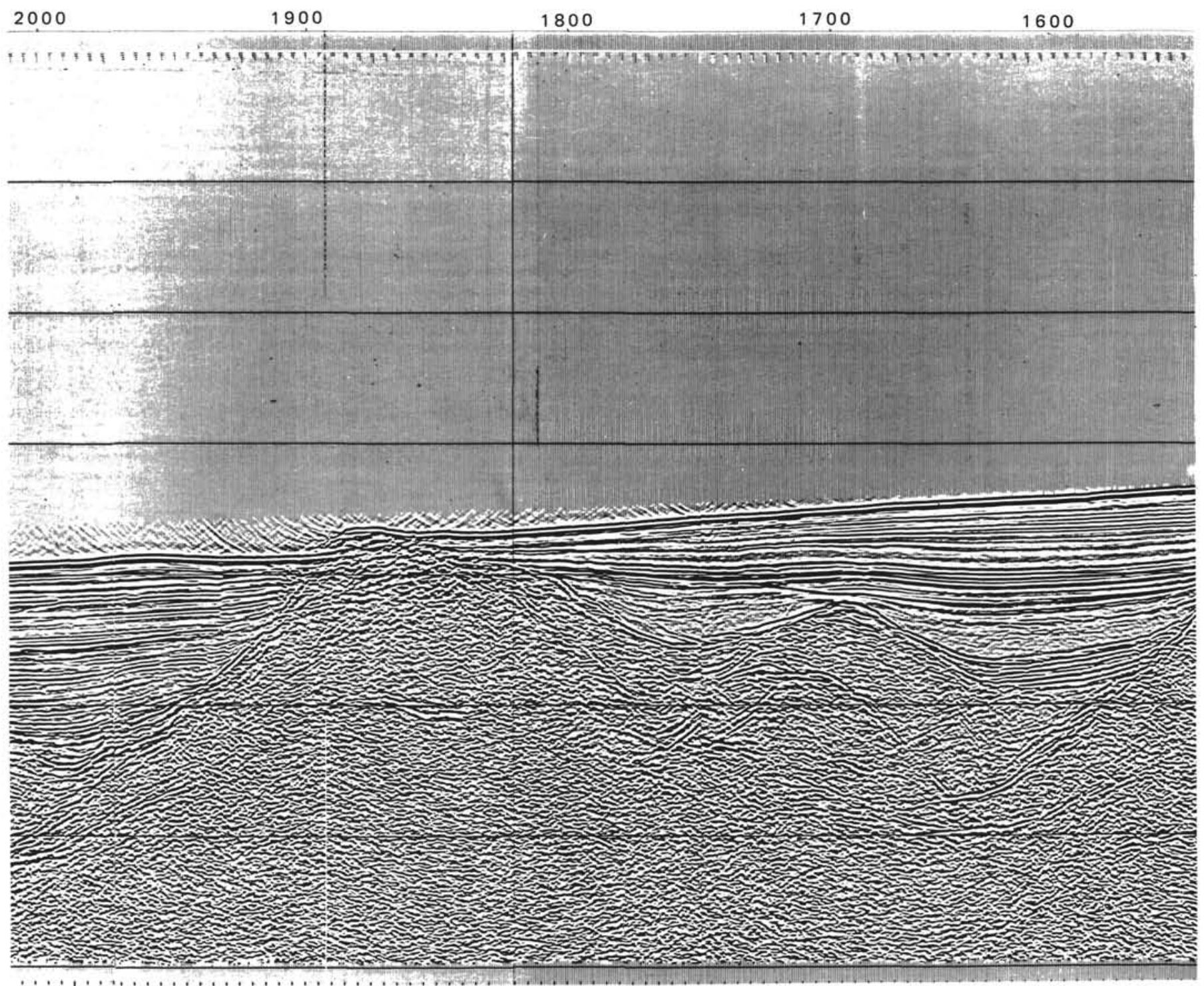

Plate 1 (continued). 
Profile GP-11

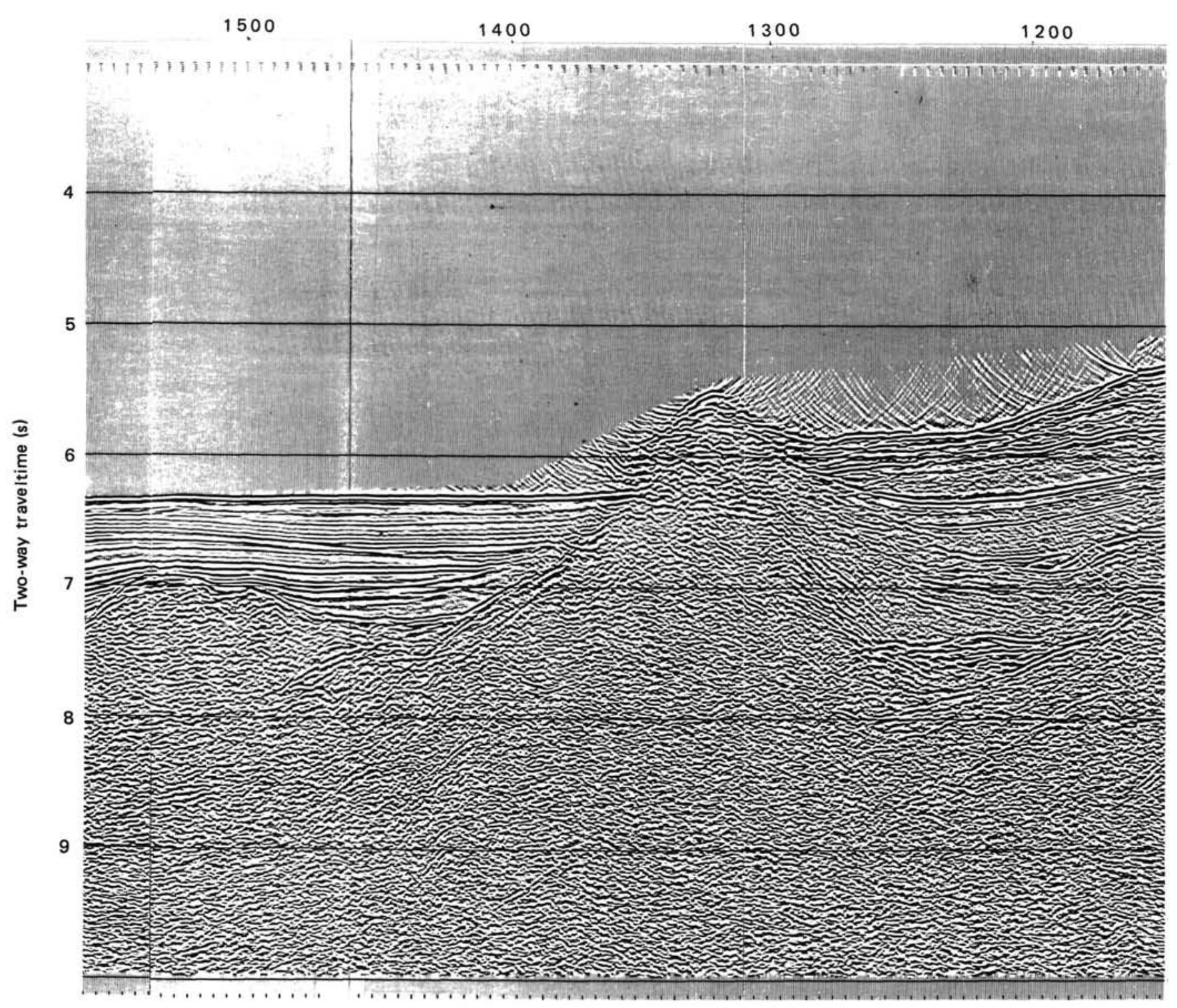

Plate 1 (continued). 
Profile GP-11

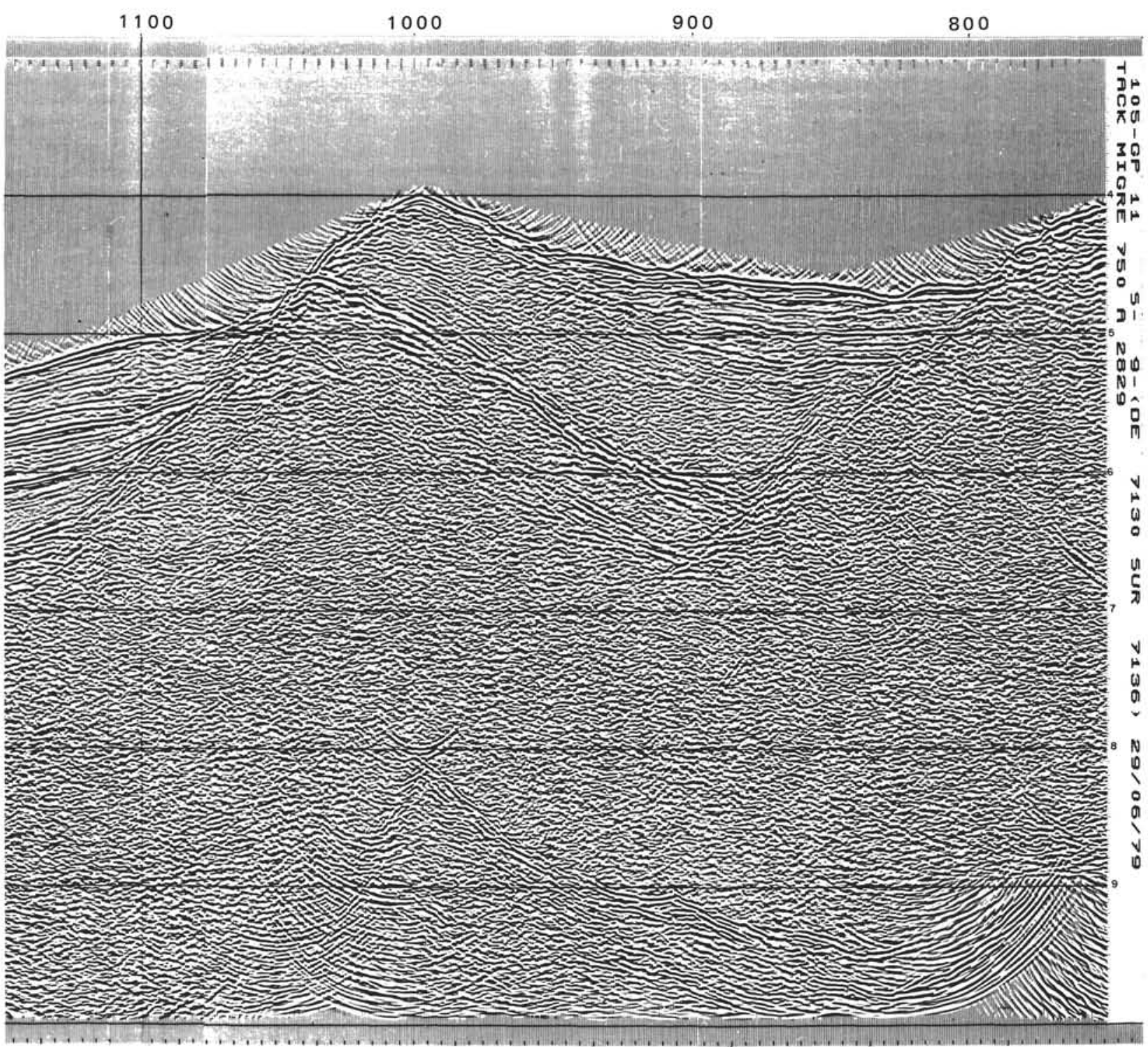

Plate 1 (continued). 


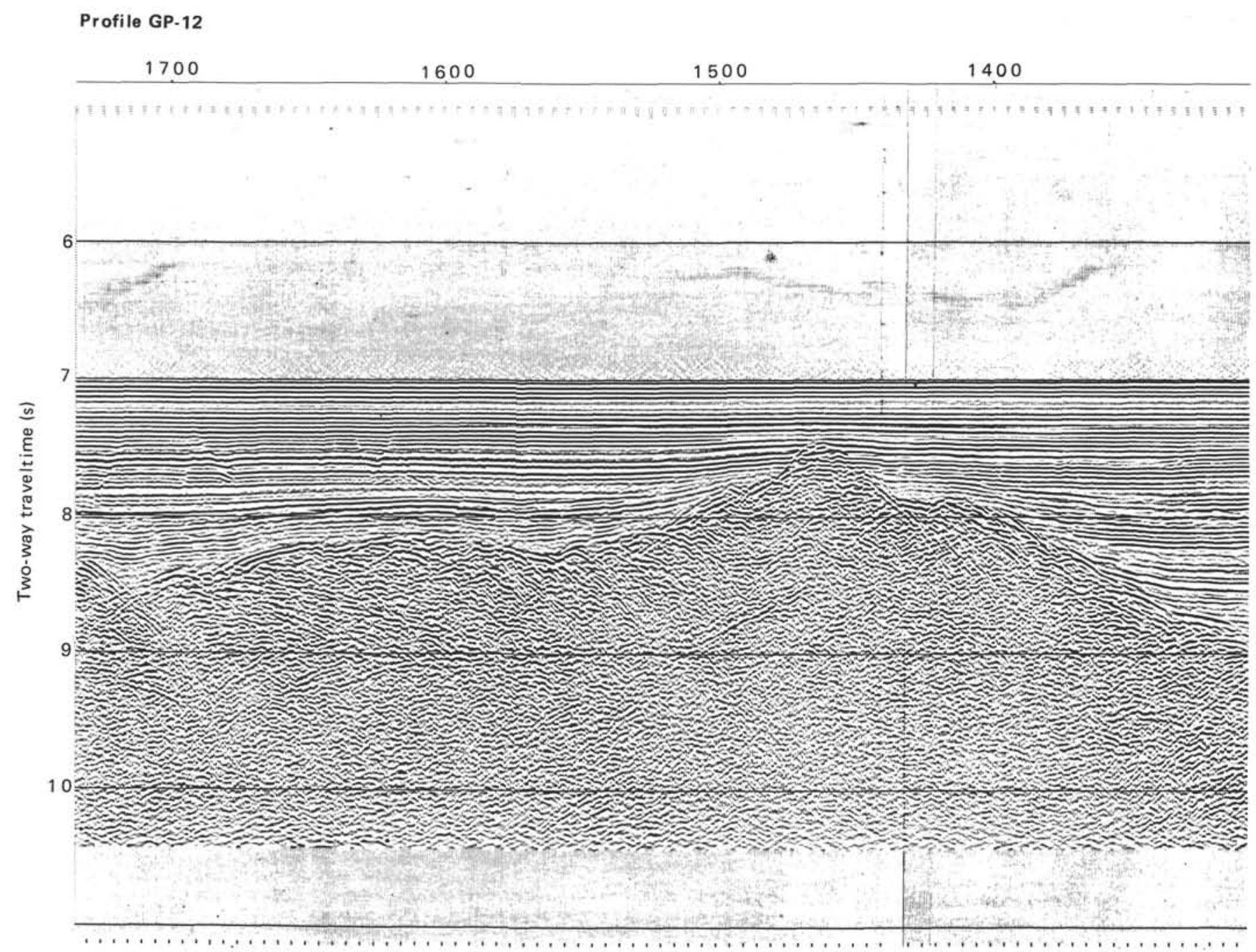

Plate 1 (continued). 
Profile GP-12

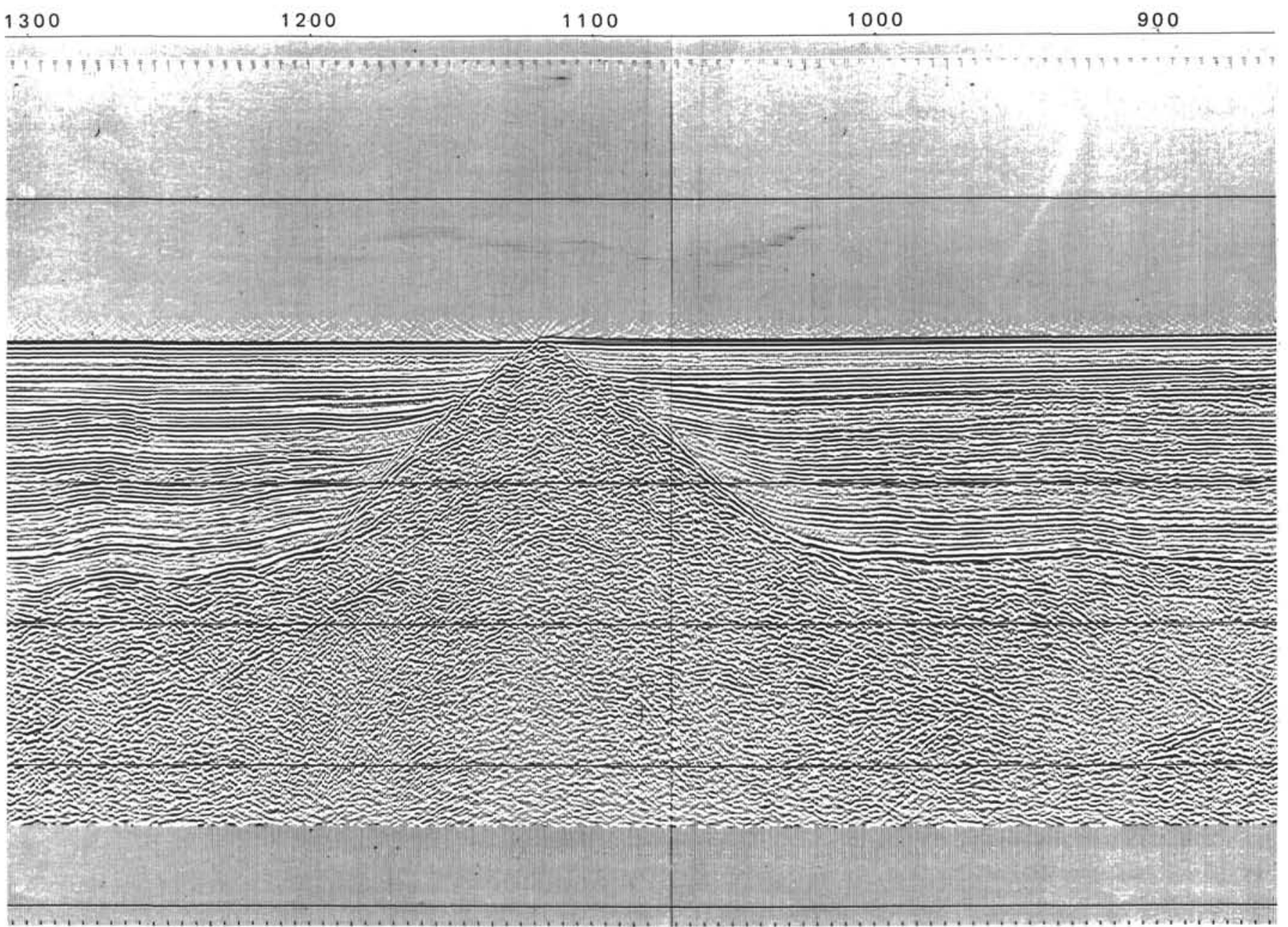

Plate 1 (continued). 
Profile GP-12

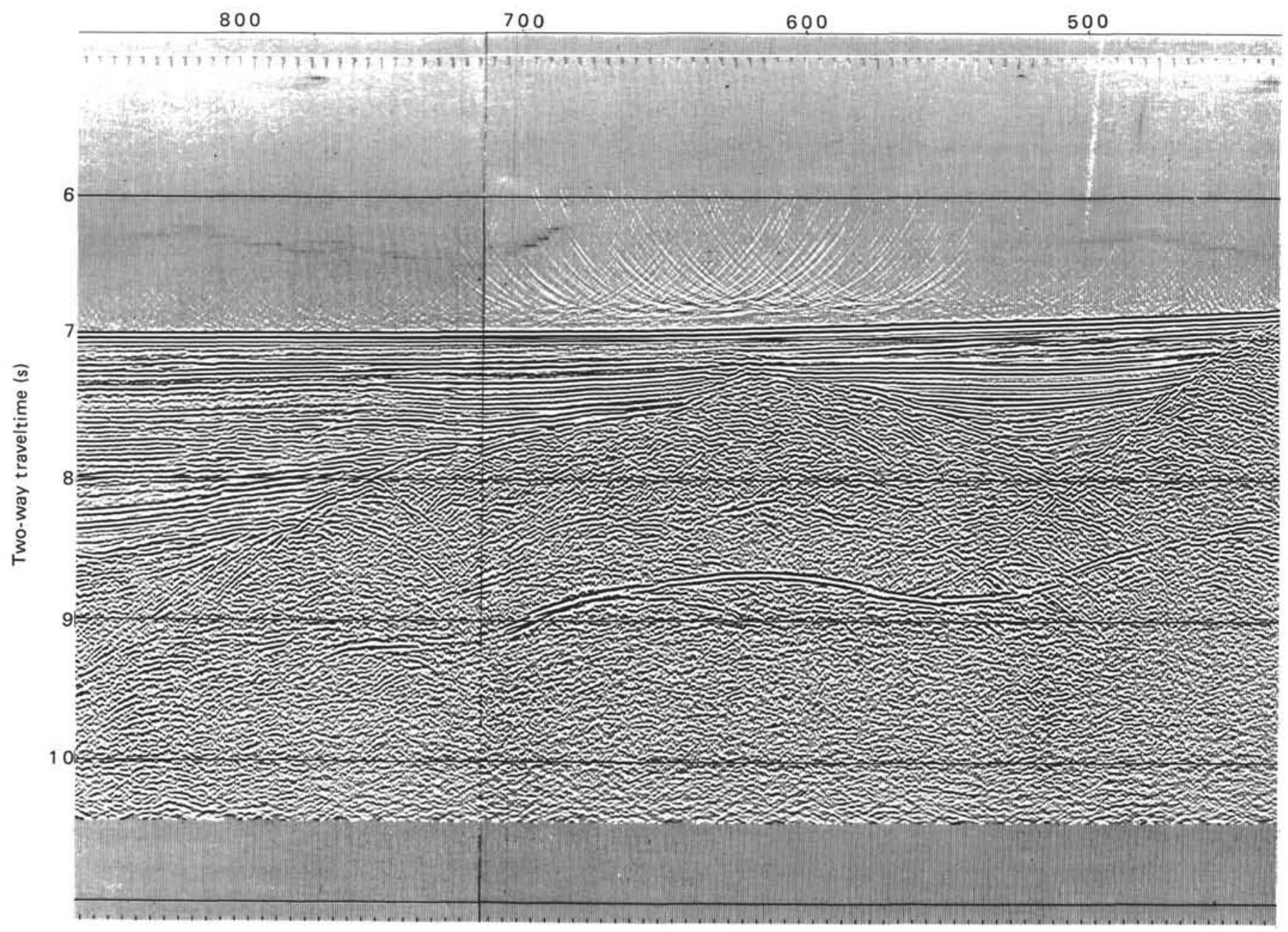

Plate 1 (continued). 


\section{Profile GP-12}

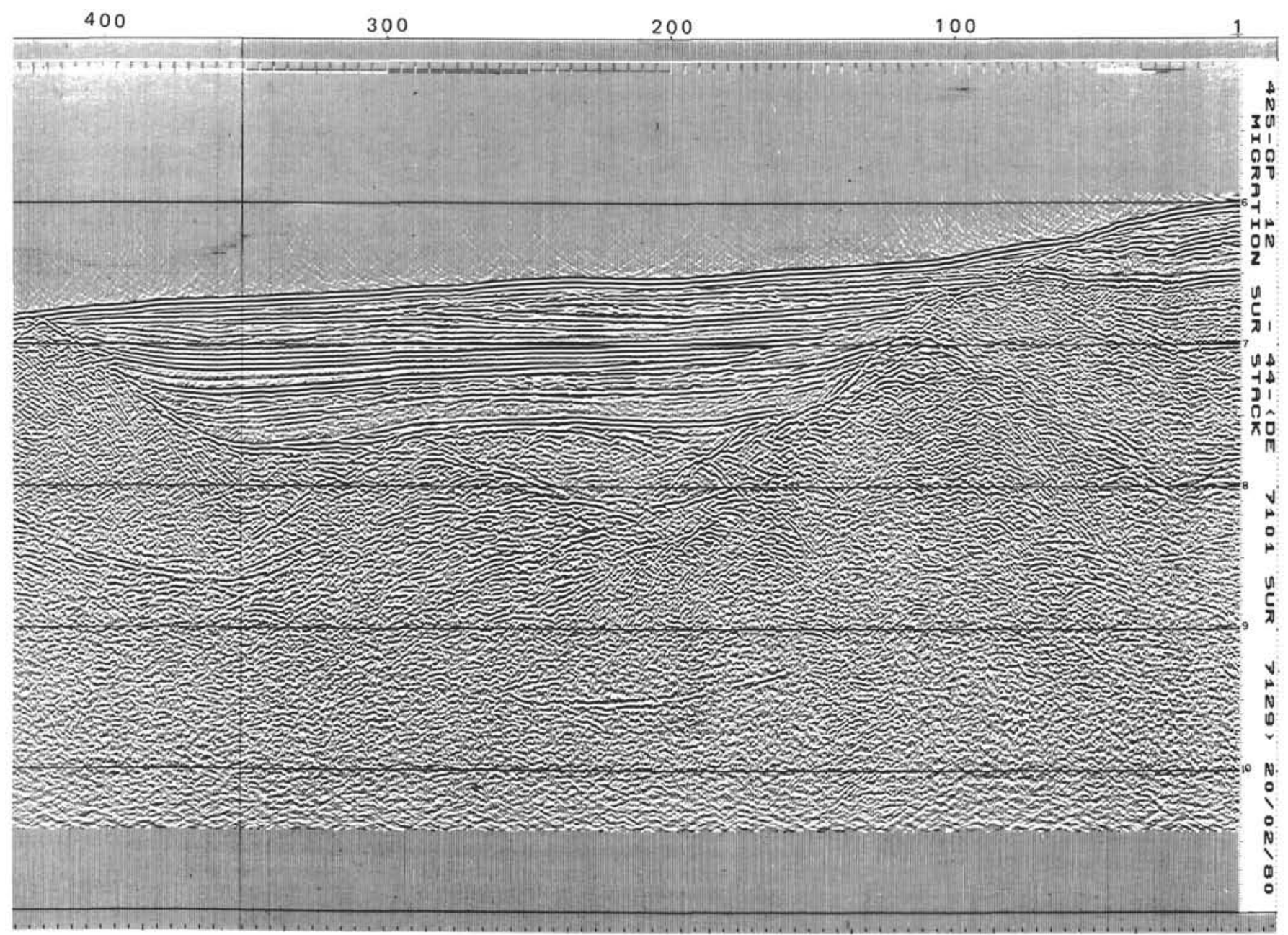

Plate 1 (continued). 
E. L. WINTERER, J. S. GEE, R. F. VAN WAASBERGEN

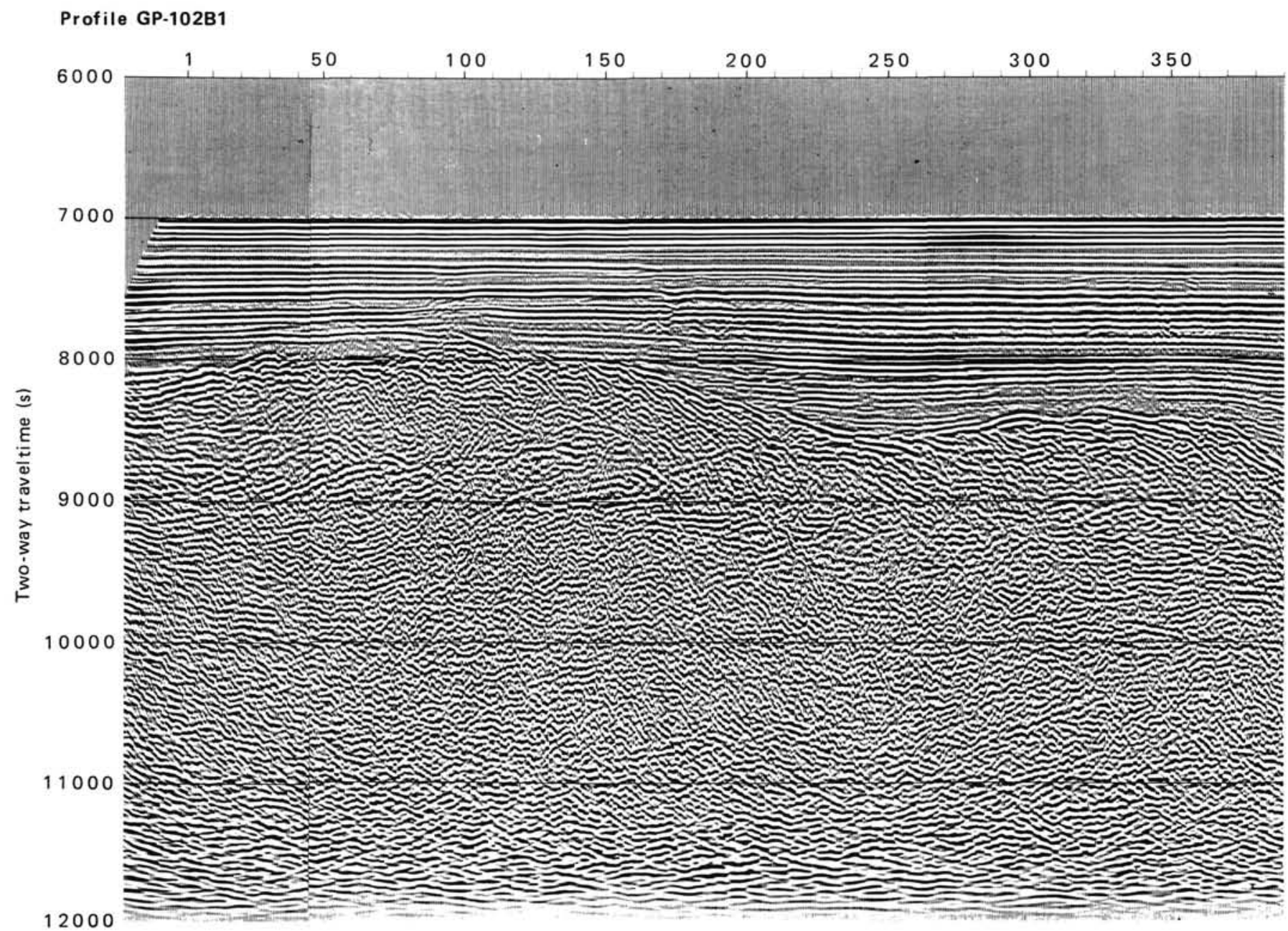

Plate 1 (continued). 
Profile GP-102B1

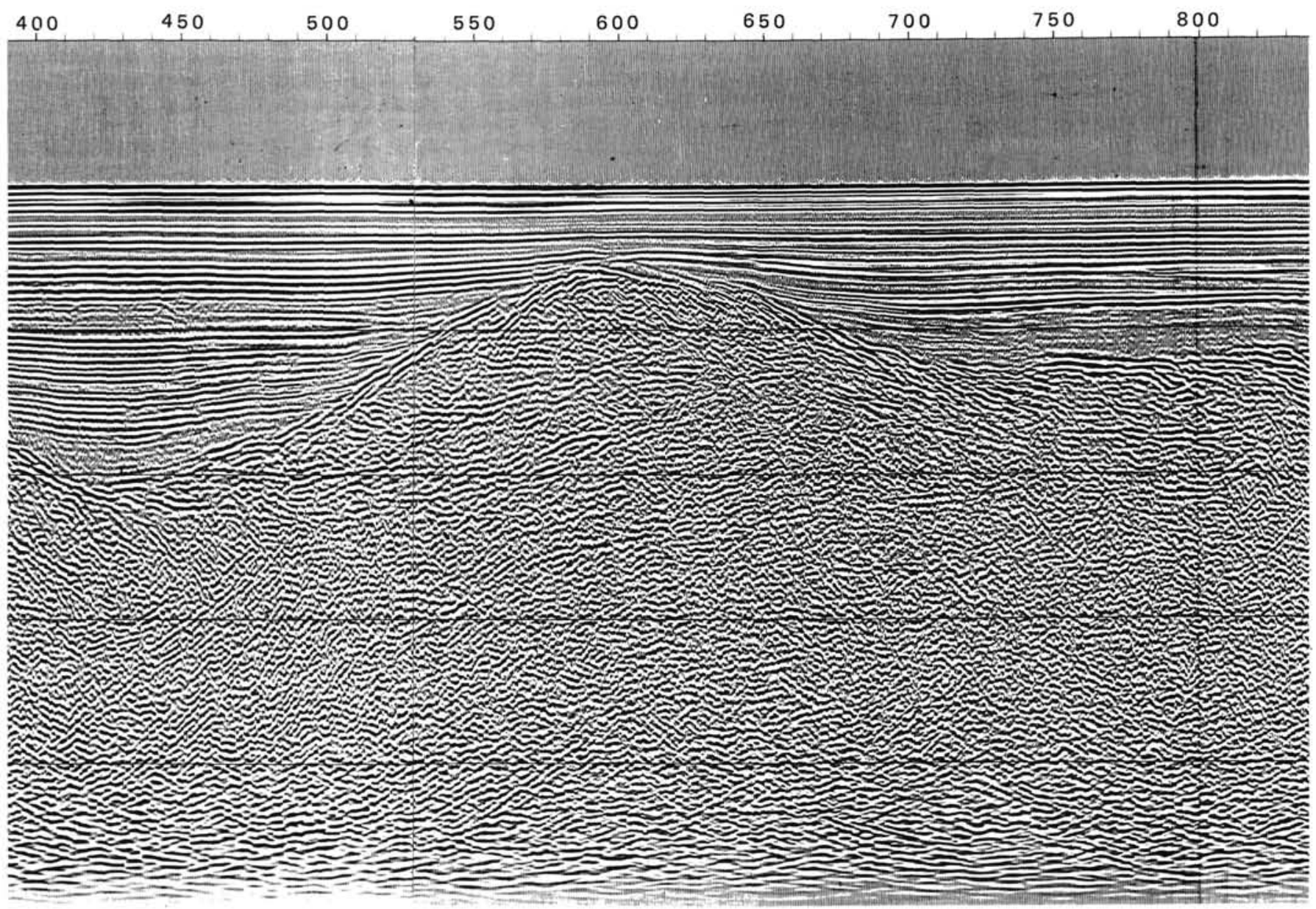

Plate 1 (continued). 
Profile GP.102B1

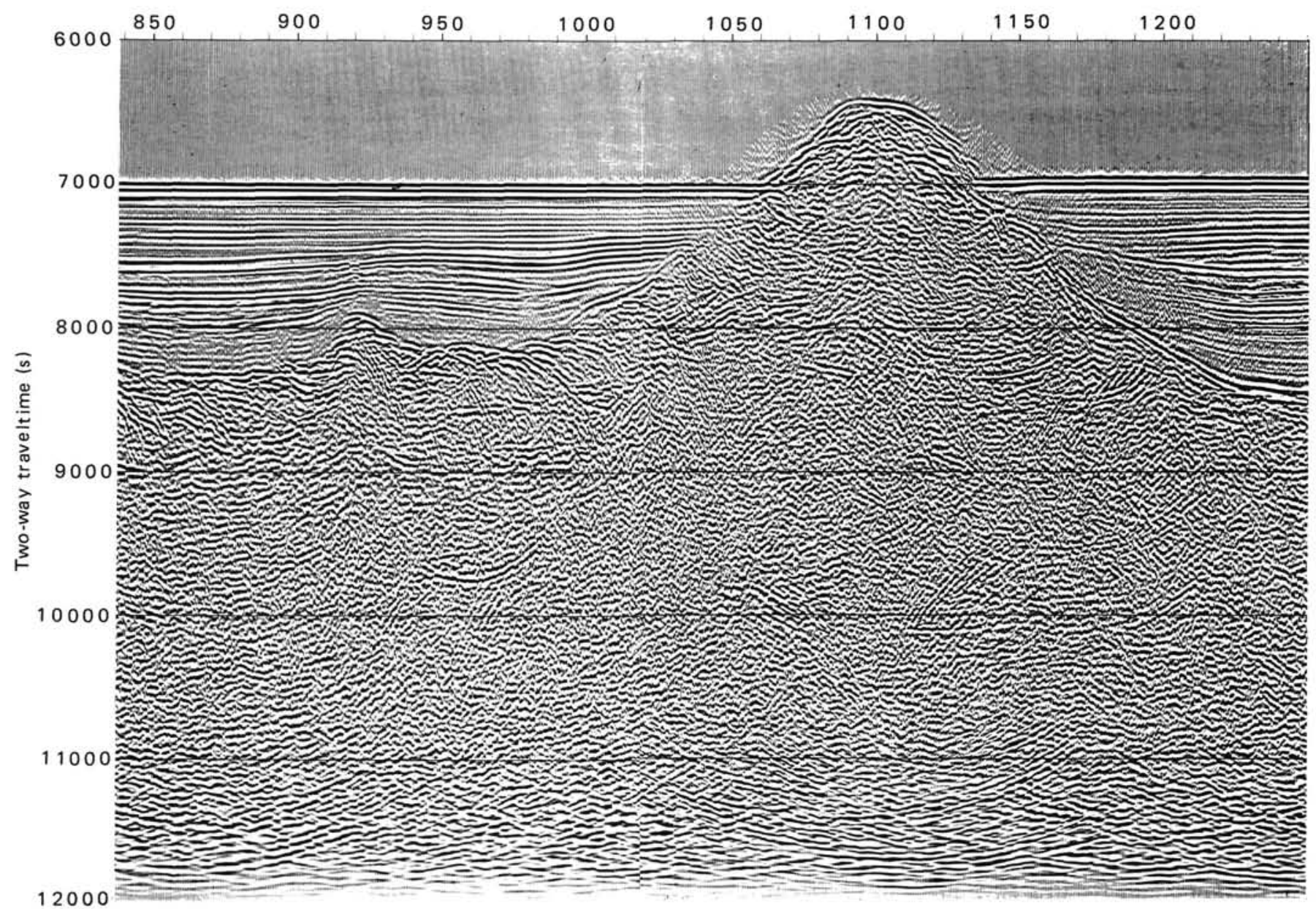

Plate 1 (continued). 
Profile GP-102B1

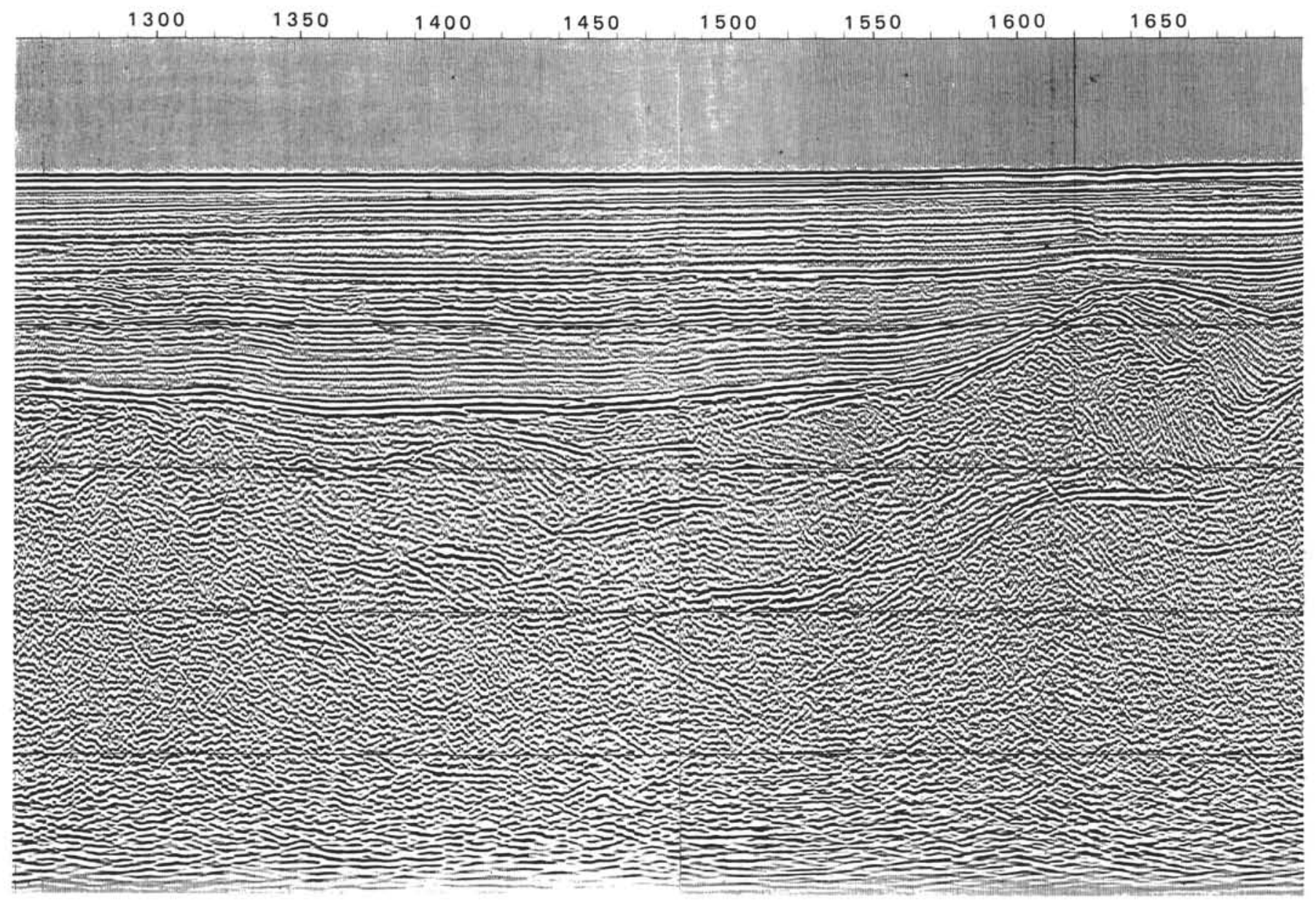

Plate 1 (continued). 


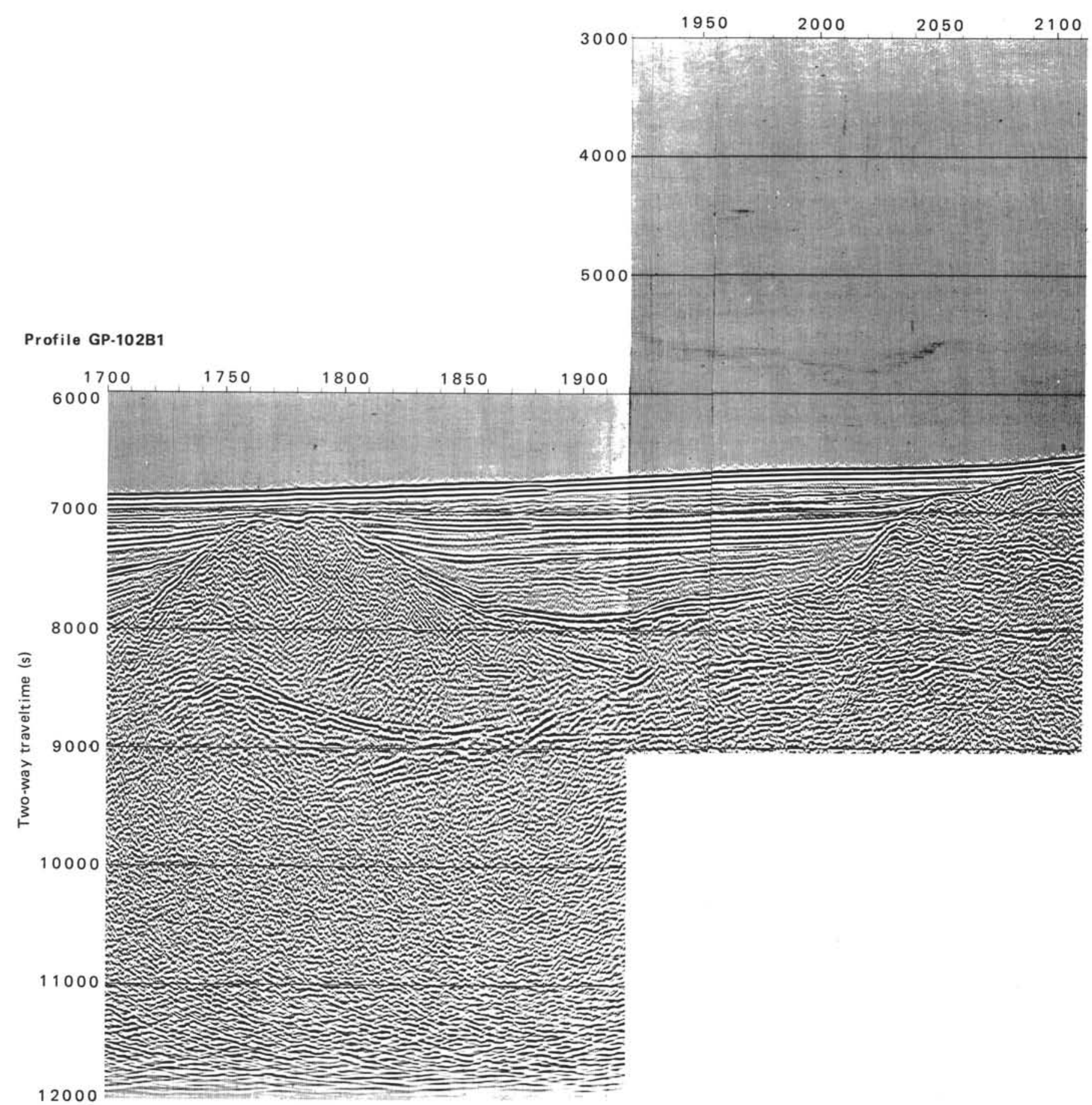

Plate 1 (continued). 
Profile GP.102B1

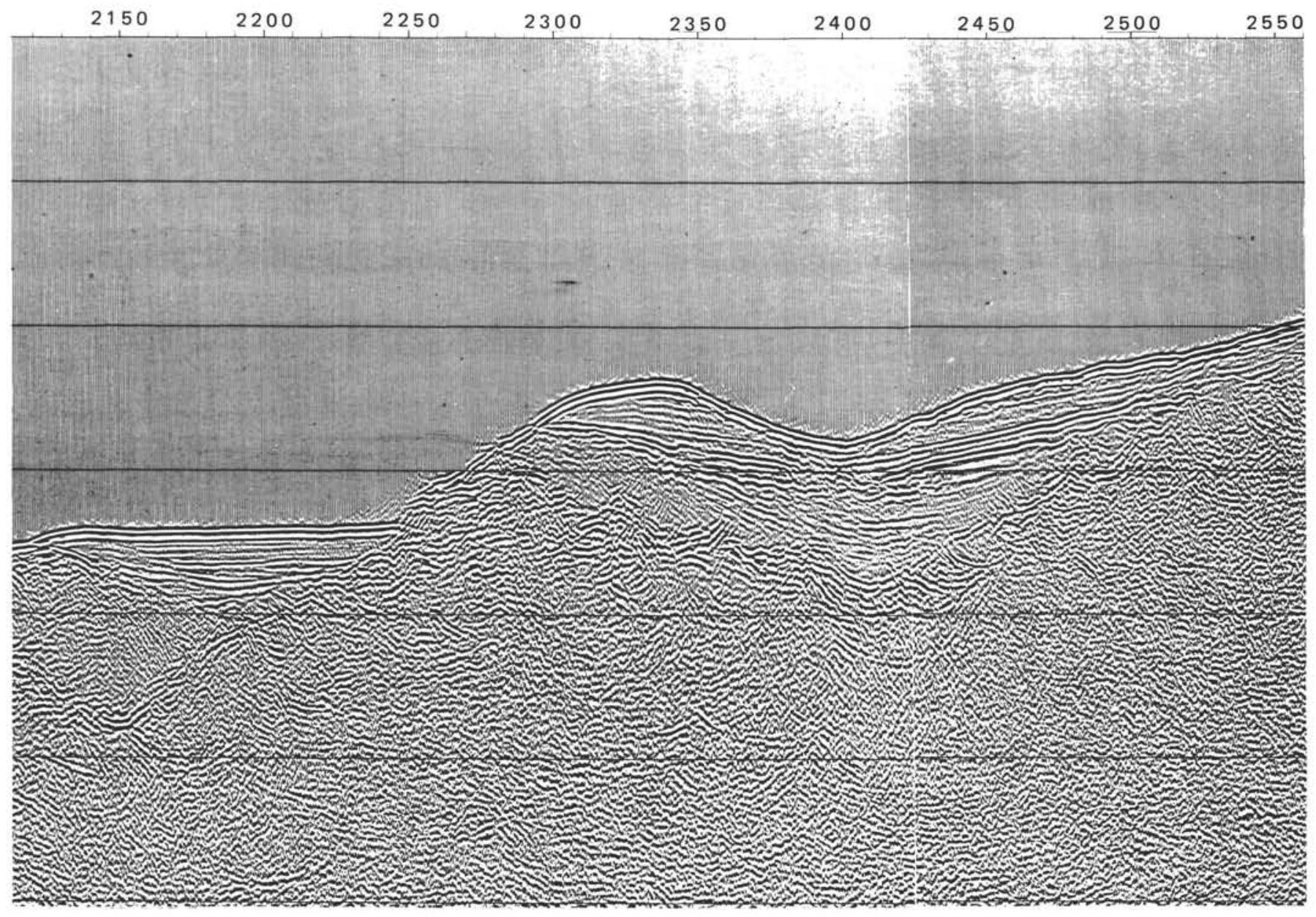

Plate 1 (continued). 
E. L. WINTERER, J. S. GEE, R. F. VAN WAASBERGEN

Profile GP-102B1

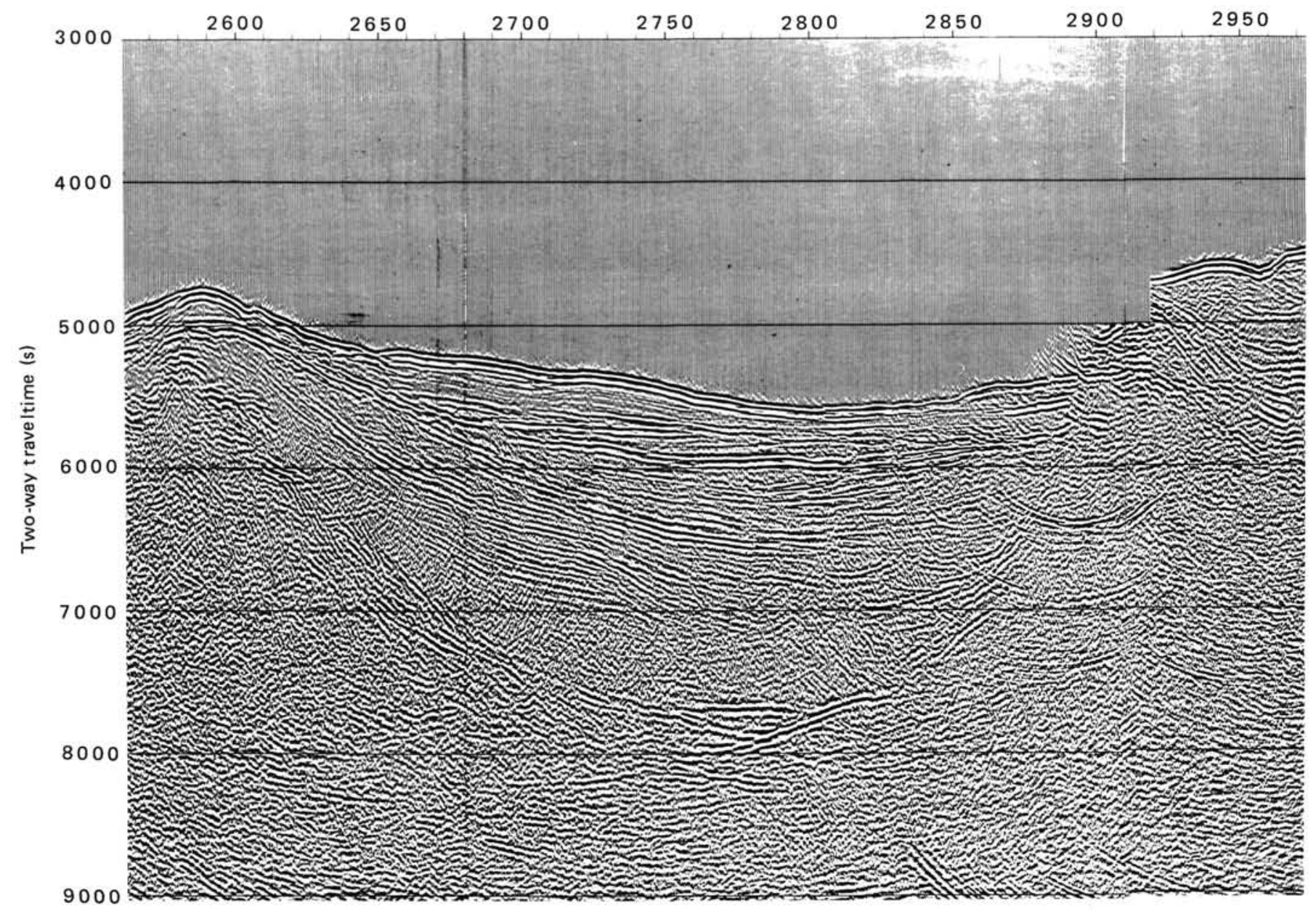

Plate 1 (continued). 


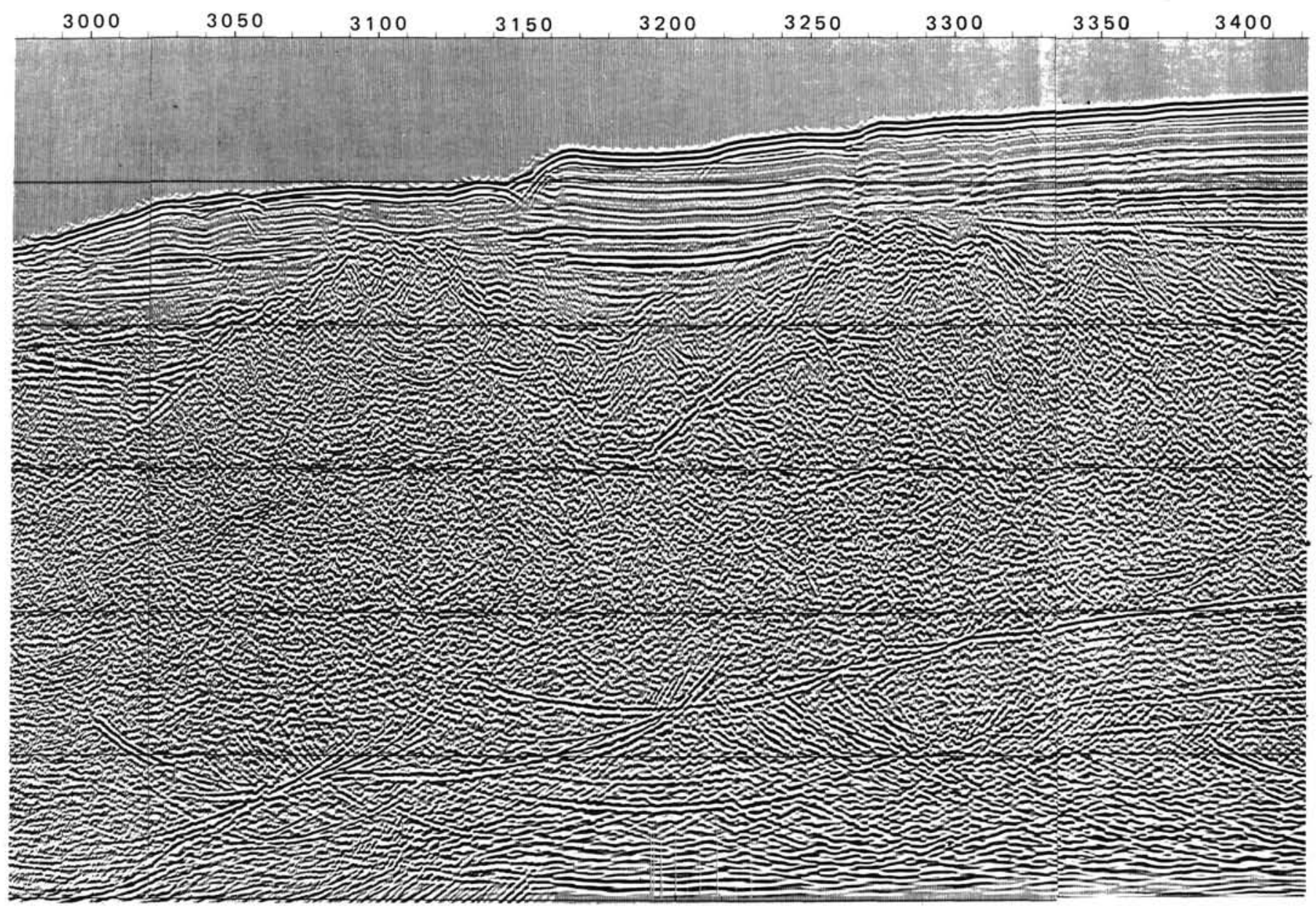

Plate 1 (continued). 
E. L. WINTERER, J. S. GEE, R. F. VAN WAASBERGEN

Profile GP-102B1

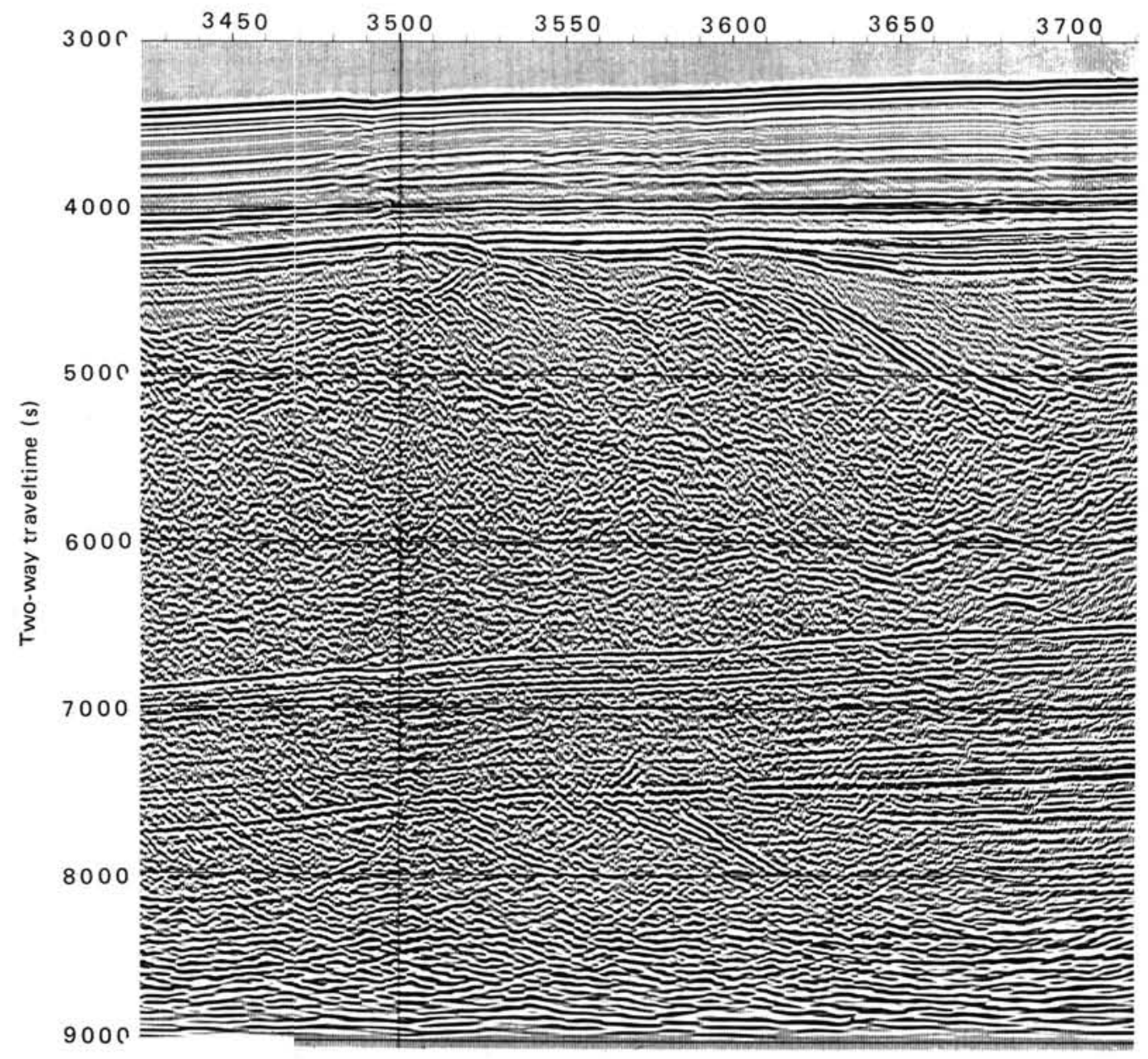

Plate 1 (continued). 